\title{
Just Peace as Ideal Theory and its Relevance to Christian Ethics of War
}

\author{
Harmon Howard Barlow IV \\ Cave City, Kentucky \\ Bachelor of Science, U.S. Air Force Academy, 1997 \\ Juris Doctor, University of Virginia School of Law, 2006 \\ Master of Arts, University of Virginia Graduate School, 2006
}

A Thesis presented to the Graduate Faculty

of the University of Virginia in Candidacy for the Degree of Master of Arts

Department of Religious Studies

University of Virginia

May, 2016 


\section{Just Peace as Ideal Theory and its Relevance to Christian Ethics of War}

"The Christian ideal has not been tried and found wanting. It has been found difficult; and left untried." G.K. Chesterton, What's Wrong with the World

Any serious Christian approach to the ethics of war-for example, those exemplified by the pacifist and just war traditions_-must reckon with the 'hard sayings' of Jesus recorded in the Gospels, especially the injunctions to turn the other cheek and to love one's enemies contained in Matthew 5. It would not be inaccurate to view these traditions as representing divergent ways of applying Jesus' commandments to the nonideal circumstances of the real world, circumstances that are presupposed in the injunctions themselves: i.e., the existence of an enemy, of someone striking one's face. If this is true (and I will argue below that it is), then both traditions can be seen as embodying nonideal ethical theories, concerned with working out the implications of the hard sayings and providing actionable moral guidance. The hard sayings, in combination with broader theological, philosophical, and ethical frameworks, provide actionable rules: in the case of pacifism, either the literal rule of nonresistance to evil or perhaps some form of non-violent resistance, and in the case of just war, a more complex set of rules designed to channel and limit the use of violence. In both traditions, the hard sayings exert an influence. In the pacifist tradition, the influence is fairly obvious, but it is there in the just war tradition as well, for those who look closely.

The divergence between these two classical approaches to the ethics of war has occasioned much conflict, because nothing less than faithful obedience to Jesus' commands is at stake. From the pacifist side, just warriors are at the very least accused of disobeying those commands, or worse, using the just war criteria as a way to appear faithful while in reality pursuing altogether different agendas of power and control. From the just war side, pacifists are accused of rigid literalism, inconsistency in relying on a peace they are unwilling 
to help maintain, and perhaps worst of all, failing to understand the true relevance of, and therefore failing to correctly apply, the teachings of Jesus to a world of violence and struggle between powers. Much has been made of this divergence, and I will return to it below, but the primary focus of my thesis is not on how the two approaches diverge, nor even how they are related directly to the hard sayings, but on how they are structurally related as nonideal ethical theories and how, if it all, are they related to an ideal theory.

It is a commonplace in the just war tradition, extending from Augustine of Hippo to contemporary philosophers like Nigel Biggar, that the aimed-for ideal of a justified war is to establish a just peace. Much has been made of the just war tradition's relationship to the teachings of Jesus and the philosophical commitments of its advocates, but relatively little attention has been given to the idea of a just peace and the role it plays in Christian ethics of warfare. The primary aim of my thesis is to articulate just peace as ideal theory and how that theory relates not only to the nonideal theory of the just war, dealing with the questions of what justifies going to war (jus ad bellum) and what it means to justly engage in war (jus in bello), but also to the nonideal theories of pacifism and various sorts of realism.

The secondary aim of my thesis, closely overlapping with the primary, is to ask what the moral relevance is of just peace as an ideal-a 'pacific ideal'-to contemporary Christians, especially Christians in a modern democratic context. ${ }^{1}$ What would it mean for the pacific ideal to be 'relevant' for contemporary Christians, and is it so? To say that an

\footnotetext{
${ }^{1}$ Hereafter I use 'pacific ideal' to mean 'just peace as an ideal'. By "Christians in a modern democratic context" I mean those who inhabit a political system where they are able to exercise, or at least understand themselves as being able to exercise, some level of control or oversight of the decisions that their political leaders make regarding war. There are plenty of examples of varying degrees of 'self-government' before what is commonly considered the modern era. However, the self-understanding of Christians in modern polities like the United States or the United Kingdom does seem to differ remarkably from that of Christians in the polities to which earlier generations of just war thinkers-from late antiquity, the medieval era, or early modernity — addressed themselves. Whether the control or oversight that modern Christians believe they exercise is real or illusory — an important question— the point is that many do believe themselves to exercise it.
} 
ideal is morally relevant to Christians would have to involve at least two things: First and most obviously, it would need to guide thinking and practice with regard to the subject at hand, which in this case is war. More on that momentarily. Second and more deeply, it would have to cohere with the commitments that Christians already make-for example, obedience to the hard sayings mentioned above or to Jesus' more exhaustive command to love one's neighbors as oneself-and extend those commitments into their moral and political lives in a way that enhanced their appreciation for the robustness and sustainability of those commitments. ${ }^{2}$ The hard sayings are not themselves ideals, as they presuppose nonideal circumstances, but neither are they merely rules to be followed, any more than 'the love command' is. ${ }^{3}$ Ethically self-aware Christian action can be, and arguably ought to be, teleologically as well as deontologically ordered. A justified war, after all, has to aim at something, and the just war tradition speaks of war's justification not only in terms of observing rules (e.g., the command to love one's enemies), but also in terms of the end that is sought: namely, a just peace. The pacific ideal is the aimed-for ideal of a justified war, and, I will argue, not only for justified war but also for non-violent resistance to evil.

And yet, while the pacific ideal is not reducible the deontic commitments that Christians already make, it necessarily relates to them. The love command may not itself be an 'ideal'; but one can hardly conceive of the Christian ideal of a just peace without it; and neither, arguably, can one conceive of how the love command is to be applied in non-ideal circumstances without such a conception of an ideal in mind. Thinking in terms of ideals is

\footnotetext{
2 In referring to Christians throughout this paper, I mean those who hold their commitment to obey Jesus in good faith; what that means in practice is obviously controversial, and may be a matter of ignorance as well as disagreement; what I mean is that if a Christian were asked if they ought to obey Jesus, even in a difficult matter, they would answer "absolutely".

${ }^{3}$ I use 'the love command' interchangeably to refer to Jesus' command to love one's neighbor with his command to love one's enemies; because the latter is an instantiation of the former, I see no need to always specify which is which.
} 
a way to incorporate both ends and rules. So the pacific ideal is not merely the aimed-for, but also the regulatory, ideal of justified war and non-violent resistance. And if it is a relevant ethical ideal, then it will not only provide clarity and guidance to the nonideal traditions of just war and pacifism, but also the internal satisfaction and confidence that one would expect from realizing, or at least aiming for and identifying with, that ideal.

What of the practical guidance that the pacific ideal would offer? It would not be merely deductive, because the pacific ideal is impossible to conceive, at least in a way that is appropriate to human life, apart from the pre-existing commitments it embodies (e.g., the love command) or the historical traditions of thought to which it relates (e.g., pacifism and just war); how exactly it relates to those pre-existing commitments and traditions is one of the subjects to be explored below. However, it would question, critique, and reinforce the nonideal traditions of thought and guidance to which it relates and also the way those traditions are used against one other. One example of this is the way that the just war tradition has often been used to argue against pacifism, a purpose it has served from its genesis, in the writings of Augustine, until today, as exemplified in the work of Oxford ethicist Nigel Biggar. ${ }^{4}$ An important and common argument against pacifism is that it does not appropriately deal with human reality, and that the pacific ideal is just that, an ideal, not to be confused with nonideal circumstances. But limiting the relevance of the pacific ideal to an argument against pacifism is a terrible mistake, because pacifism represents only one end of the spectrum of Christian attitudes toward war: What of the thousands of Christians who serve in the military, or perhaps more importantly, what of the millions of non-pacifist

\footnotetext{
4 Augustine of Hippo was not the first to write on the justice of war (see, e.g., Cicero's De Officiis), but the Christian articulation of a theory of just war arguably began with him. For Biggar's argument against pacifism, see chapter 1 of In Defence of War, Oxford: Oxford University Press 2013.
} 
Christians who identify themselves as citizens, who vote and engage in other forms of political participation that bear on their country's foreign policy? It is likely that the great majority of them already reject pacifism on the grounds that it is not 'realistic'. What further relevance does the pacific ideal have for them? If the pacific ideal, or something like it, is necessary to embody the commitments that Christians have already made, then articulating how exactly that ideal remains binding even in nonideal circumstances is of the utmost importance for the integrity of any nonideal ethical theory that purported to be faithfully Christian. The just war tradition sees enough continuity in the human realms of peace and war to hold that warfare, however horrific and even absurd in reality, not only requires justification on an ethical basis, but indeed cannot even be properly understood apart from ethical norms. And yet these norms are not derived from the conditions of war; they are the norms of peace. The pacific ideal is not merely the aim of a justified war; it is also, in some sense, the source of the norms that guide and make sense of ethical (or unethical) behavior in war. Again, it is not only the aimed-for, but also the regulative, ideal of a justified war.

If it is the case that the pacific ideal pervades the nonideal theory of the just war, then it is bound to leave its traces on other nonideal theories of war, such as pacifism or Niebuhrian realism. Besides serving to question, critique, and reinforce those approaches to war, the pacific ideal sets boundaries around what can rightly be considered a Christian ethic of war. Obviously, an explicit or implicit rejection of the moral teachings of Jesus and the other New Testament writers would render a theory non-Christian. Arguably, the same goes for any nonideal theory of war that has as war's intended aim a state of affairs incompatible with a just peace, or any nonideal theory of war where the norms of the pacific ideal leave no trace, either normatively or descriptively. These too are rendered non-Christian. Finally, the 
pacific ideal reaches beyond the ground covered by current Christian nonideal theories and can be applied to situations not currently addressed by those theories. For example, how nonideal just war theory provides moral guidance to rulers in the decision to go to war and to soldiers in the conduct of war is fairly well-articulated and well-known. But certain aspects of a modern Christian's life, particularly those that relate to the Christian as citizen rather than soldier, largely elude the guidance that the just war tradition provides. To the extent that nonideal theory as currently conceived is not adequately articulated for political life, it fails to provide arguably much-needed moral guidance. Reflection on those aspects of modern life in light of the pacific ideal has the potential to bridge this gap.

I will pursue the two aims of my thesis_-first, to articulate just peace as an ideal theory and its relationship with nonideal theories like just war and pacifism, and second, to articulate the relevance of that pacific ideal for Christian ethical thought and practice-as follows: The first task and the subject of Part I is to outline the conceptual relationship between ideal and nonideal theory and to identify those elements of an ideal theory that are necessary for serving as both the aimed-for and regulative ideal of nonideal policies. Before developing just peace as an ideal theory, however, Part II lays out the biblical sources of Christian moral commitment and begins to describe how the nonideal traditions of just war and pacifism diverge in their handling of the conflicting moral commitments that scripture seems to enjoin, a divergence that will be important to address as part of ideal theory. Part III extends the discussion of conflicting moral commitments in dialogue with the work of contemporary just war theorist James Childress, in terms of prima-facie duties, which relate importantly to the ideal/nonideal distinction developed in Part I and the development of the pacific ideal. Part IV, the heart of my thesis, develops the idea of just peace as a Christian 
ideal, as both the aimed-for and regulative ideal of Christian nonideal practice with regard to war. Part V returns to the nonideal traditions of pacifism and just war, as well as a variety of realist traditions, and closely examines them in light of the pacific ideal. Moreover, those strands of realism, just war, and even pacifism that would not qualify as Christian in light of the pacific ideal are identified and delineated. Finally, Part V also questions the relevance of the pacific ideal for modern Christian political life, particularly whether it has the resources to call out and chasten practices that are inconsistent with the moral commitments that Christians already make and are embodied in the pacific ideal.

My contention throughout is that the pacific ideal represents an important aspect of the Christian ideal to which Chesterton refers in the epigraph above. Throughout history, where it has been acknowledged and properly articulated, it has not been tried and found wanting, but rather usually found difficult and left untried. But to the extent that it remains unknown, unacknowledged, or inadequately articulated, its challenge to modern Christians is incomplete, and the nonideal moral guidance that they inevitably must employ, especially in the realm of political life, will be the poorer for it. Part of taking the pacific ideal seriously is to reflect on its relevance to circumstances unforeseen by those who originally articulated it, and that is one of the aims of this paper. My hope is that the pacific ideal properly extended would not be found wanting, would be found difficult, and would be tried.

\section{Ideal and Nonideal Theory}

In the introduction, I referred to the biblical sources of moral guidance and the traditions that embody them as nonideal, not (necessarily) because they fall short of what they ought to be, but because they clearly apply to nonideal realities and they were quite apparently formulated with those realities in mind, however idealistic or even impossible 
they may be (as in the case of the love command). The fact that the nonideal pacifist and just war traditions were largely formulated without having worked out a systematic understanding of the relationship between ideal and nonideal ethical theory beforehand may call into question the need for ideal theory at all. Why should we bother with ideal theory when we have the biblical commands and the developed traditions already? There are at least two reasons why we should: First is that the just war tradition explicitly prescribes an ideal to be kept in mind whenever a war is evaluated for its morality-the ideal of a just peace-and whether that ideal has been worked out sufficiently or not in the tradition does not detract from its relevance as a part of the tradition. My view is that is has not, and that is one of the primary aims of this paper, largely taken up in Part IV. Second is that the relationship between ideal and nonideal theory is more complicated than simply having an ideal end in mind when one acts under nonideal circumstances; that relationship and some of the controversies it involves are worth exploring.

Before taking up the relationship between ideal and nonideal theory, however, one thing needs to be said about how ideal theory relates to everyday morality. Everyday activity is structured both deontologically and teleologically, usually without much explicit thinking. ${ }^{5}$ Consider making dinner plans with a group of friends: The envisioned outcome, or telos, governs the process from the beginning, as soon as the idea is conceived. And it is usually not the case that any of the participants are stopping to ask what an 'ideal' dinner out looks like, much less a morally ideal one. Such explicit thinking is unnecessary because both moral (and non-moral) norms are already operating in the background: e.g., "let's make sure to

\footnotetext{
${ }^{5}$ For a fantastic, non-academic discussion of how this works in everyday life, see David Allen, Getting Things Done, New York: Penguin Books 2015, chapters 12-13 on next-action and outcome-based thinking.
} 
invite Heather, because she is new to the area" or "let's not eat at Boylan Heights, because it is loud and William has a hard time hearing". Even the explicit outcome-in this case eating dinner with friends - is usually embedded in ongoing, or dialectical, activities that are already in progress: e.g., pursuing friendships, creating space to relax, learning to appreciate good food, cultivating gratitude for life's blessings, etc. ${ }^{6}$ These are the activities that make up a 'good' life, and embarking upon them does not require that the good to be enjoyed through them be understood at the outset; in fact, such understanding is impossible and can only be grasped or unveiled by engaging in the activities over time. The concept of 'ideal' is only relevant or appropriate to the central activities of everyday life after the fact, once the form of the activity is grasped by reflection upon one's engagement in it. In any case, ideal theory in moral life is not to be understood as the need to hammer out what the 'ideal' life looks like before one embarks upon it. The open-endedness of life, even moral life, disallows it.

There are activities, however, which quickly push us in the direction of being explicit in our moral thinking, and therefore in the direction of thinking in terms of ideals. Consider the same dinner as a prelude to an intervention: e.g., "William's narcolepsy is becoming a problem and he is dealing with it in a self-destructive way; if we care about him, we will say something", "we should tell him about why we are going to dinner, but he might not come if we do", "we need to communicate in a way that does not feel intrusive to him". There are prima facie obligations at stake, such as being honest with or respecting the privacy of one's friends, or not causing another to feel awkward by bringing up deeply personal issues. ${ }^{7}$ They are not absolute obligations, but they leave a moral trace if they are broken, and we can think

\footnotetext{
${ }^{6}$ On the idea of 'dialectical' activity and the moral psychology of action that underpins it, see chapters 1-2 of Talbot Brewer, The Retrieval of Ethics, Oxford University Press, 2009.

${ }^{7}$ I take up the theme of prima-facie obligations in much more detail in Part III.
} 
of them in terms of ideals: "it ought not to be this way, ideally". Ideal theory becomes relevant when activities need justification or legitimation. Due to their pervasively coercive and violent natures, modern political society and war are such activities.

The distinction between ideal and nonideal theory, like much else in modern moral and political philosophy, can be traced to the monumental work of John Rawls, $A$ Theory of Justice. Rawls develops his ideal theory of "justice as fairness" out of an imagined social contract between participants who know all of the necessary facts of human psychology and social institutions but do not know what place they will occupy in that society; out of this "original position" come two principles of justice that are to regulate the basic institutions of society. ${ }^{8}$ The content of Rawls's ideal theory of justice, as well as his idea of using a social contract to derive it, have been endlessly debated. Much less attention has been paid to his use of the ideal-nonideal distinction, which, according to contemporary political philosopher John Simmons, was Rawls’s “proposed solution to the venerable problem of characterizing

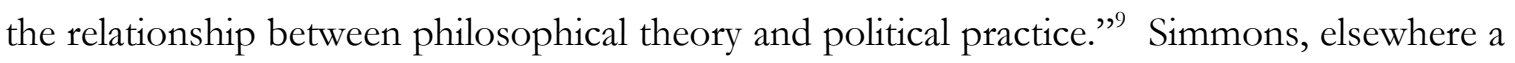
critic of Rawls's ideal theory, reconstructs the Rawlsian ideal-nonideal distinction and defends it against its detractors, both of which are relevant to our purposes. In brief, ideal theory articulates a conception of justice that we ought to aim for, and nonideal theory specifies the principles to follow and the means to employ in moving towards that ideal. ${ }^{10}$

Simmons illuminates two aspects of Rawls's conception of ideal theory that would apply to any ideal theory of justice, not just his own, and would certainly apply to the ideal of

\footnotetext{
${ }^{8}$ John Rawls, A Theory of Justice, Cambridge: Belknap Press of Harvard University Press, 1999, DS 2-4, 11-12, $20-26$. 9 A. John Simmons, "Ideal and Nonideal Theory", Philosopby \& Public Affairs 38:1, Wiley Periodicals 2010, 6. Simmons' article is motivated by the lack of attention given to, and inadequacy of the criticism leveled at, Rawls's distinction.

${ }^{10}$ For example, if the conception of justice in view included a respect for life, ideal theory might describe a social situation where there was no murder or intentional homicide, while nonideal theory might provide for enhancements of well-being and deterrent measures to reduce its likelihood and institutions of judicial reprobation to punish its occasions.
} 
a just peace: First is the requirement that the ideal theory be 'realistic', in that the situation it describes and the moral principles derived from it not be at odds with the fundamental facts of human moral psychology and social institutions (7). To the extent that the 'facts' that we currently see as 'fundamental' are in fact historically contingent, ideal theory is itself a moving target which can develop over time. Nevertheless, it aspires to be realistic. For example, an ideal theory about the distribution of economic goods would need to take into account the facts about how economic information is attained and to what extent it depends on certain institutional arrangements, and not simply assume that social planners would have access to such information. Or an ideal theory about obligations of justice toward others would need to take into account facts of moral psychology regarding the attachment people have to their close relations or their own bodies. It might be argued that these psychological or institutional 'facts' are only social constructs, but for a proper ideal theory, that argument has to actually be made, not merely assumed, and nonideal theory would then bear the burden of explaining how the social construct is to be changed.

Second is the assumption of strict compliance with the moral principles derived from the ideal theory, a manifestly unrealistic assumption that seems to contradict the requirement that the ideal theory be realistic. Rawls, in Rousseau's words "taking men as they are and laws as they might be", describes this_-somewhat unfortunately_as a "realistic utopia"."11 But images of fantasy or perfection are not intended. The only utopian element in view is that people fully comply with the principles that are taken to be ideal; as if, for example, in a regime where murder was outlawed, there were simply no murders. Simmons defends this assumption on the grounds that only by assuming strict compliance can ideal theory get "up

${ }^{11}$ John Rawls, The Law of Peoples, Harvard University Press, 1999, 7 (hereafter LOP in parenthetical references). 
and running" as a way to realistically compare alternative ways of ordering social relations (89). If we did not assume strict compliance, then our (presumably hypothetical) comparisons between ideal theories would have to account for varying degrees of compliance in addition to the differences in results due to the principles themselves. (This is an acute problem for Rawls's theory in particular, because it depends on a social contract model where principles are being chosen and where a high premium is placed on stability.) Simmons is careful to point out that the assumption of strict compliance is not to be taken as an assumption that just any set of ideal principles would be likely to generate compliance; the criterion of being realistic still applies, and a conception of justice that is unlikely to generate compliance would be rejected (9). For example, a utilitarianism that required anyone with two healthy kidneys to donate one to someone who had none would likely fail on account of the facts of moral psychology and thus be rejected in ideal theory. There is, in addition to the reasons given by Simmons, one more reason to observe strict compliance in ideal theory: what is ideal about ideal theory is precisely that it includes not only a sort of common moral acknowledgment or commitment among members of a given society, but compliance with those commitments.

In Simmons' reconstruction of Rawls's ideal-nonideal distinction, the purpose of nonideal theory is to move us towards the goal of ideal theory by dealing with the problem of partial compliance. Simmons distinguishes the part of nonideal theory that deals with deliberate partial compliance (e.g., aggressive war) from unfortunate partial compliance (e.g., a stunted political society due to extreme poverty), and he further distinguishes 'paternalistic' actions that may temporarily not comply with certain aspects of ideal theory in order to preserve the possibility for eventual full compliance (e.g., regulating political participation to protect the continued existence of political liberties) (12-17). Because we are concerned here 
with just peace as an ideal theory, we will primarily be dealing with the problem of deliberate partial compliance (and also the need for paternalistic action) rather than unfortunate partial compliance, although the two are likely to be related in nonideal circumstances.

However, nonideal theory is not simply about identifying the ideal state of affairs and working towards it by the most direct route. Ideal theory casts a shadow over nonideal principles and methods in another important way, as a regulative, not just an aimed-at, ideal. Rawls articulates this regulatory aspect by saying that nonideal policies must be "morally permissible", "politically possible", and "likely to be effective" (LOP, 89). Regarding the requirements that nonideal policies be politically possible and likely to be effective, Simmons acknowledges that such judgments will depend on the 'expertise' of political scientists, economists, and psychologists (a fact that perhaps should not inspire too much confidence in the project), as well as specialized knowledge of the situation in view (19). A humble acknowledgment of uncertainty seems to be important part of any adequate nonideal theory. The regulative role itself of these two requirements seems straightforward, because they so closely relate to ideal theory as something to be aimed for, but it is not without controversy altogether. Simmons commends a strongly 'transitional' view of Rawls's nonideal theory, where policies that jeopardize the achievement of the just ideal are disallowed by nonideal theory, even if they seem to result in comparatively more justice in the short run (21-25). How this transitional aspect of nonideal theory is embodied in just war criteria like proportionality and reasonable chance of success is one of the topics of Part V. But the criteria of political possibility and likely effectiveness seem to stand in a different relationship to ideal theory than the criterion of moral permissibility, in that while they relate more closely to ideal theory as the aimed-for ideal, the latter seems to be more of a regulative ideal 
in its own right. How that can be the case is an important topic to be explored if we are to understand the way that the pacific ideal regulates nonideal approaches to warfare.

Part of the criterion of moral permissibility is to deal with the problem of moral costs in transition, and there are at least two ways that nonideal policies can involve moral costs. Simmons identifies one of them as 'transitional unfairness', as when innocent parties have come to rely upon unjust institutional arrangements and must bear the cost of transitioning away from them (20-21). A just peace, for example, may require that a territory previously taken in an unjust war be returned to the descendants of its former occupants, in which case some relatively innocent parties are likely to be adversely affected. A similar, if not perfectly analogous, cost is the burden of waging a justified war for the sake of instituting a just peace, which may fall on those who had nothing to do with the original injustice but are now asked to bear the cost of redressing it. In deciding whether a nonideal policy is morally permissible, such costs have to be taken into account. Another way that nonideal policies can impose moral costs is in the moral traces that remain when prima facie obligations are violated. Nonideal theory envisions situations where prima facie obligations may have to be compromised, which results in moral costs, and these costs should be taken into account. Much more will be said about prima facie obligations in Part III and about how moral costs are accounted for in nonideal theory in Part V.

But moral permissibility in nonideal theory is not only concerned with accounting for and weighing moral costs. There are presumably also actions that are absolutely forbidden, regardless of their contribution to the aimed-for ideal. Simmons mentions in passing that "plainly impermissible" acts, "such as murdering...stubborn opponents", are clearly prohibited in nonideal theory (20). But he doesn't say why this should be the case, nor does 
he elaborate what basis there is in ideal theory to prohibit such actions. Why should outright murder not be allowed if it is a likely effective and politically possible means to achieving the aimed-for ideal state? Why should moral permissibility have anything more to contribute than weighing the moral costs of murder against the progress towards the ideal? For ideal theory to have anything to say about this depends on two factors: First is the content of the ideal theory itself, the moral commitments it embodies and whether they are conceived of as absolute or not; this factor is intrinsic to the ideal in question. Second is not intrinsic to the ideal, but rather how the relationship between the ideal and the nonideal state is conceived; in the case of war, what is the relationship between peace and war and peace again? What happens to moral obligation in shifting from one to another? These two factors- the content and 'status' of moral commitment—are the subjects of the next two sections.

\section{Divergence over the Biblical Sources of Moral Commitment}

Before being tested for what is structurally required of it by nonideal theory-e.g., realism, or standards for moral permissibility_and ideal theory has to be formed, and that means attention to the sources of moral commitment that it is to embody. A claim made in the introduction and worth stating again is that any social teaching that represents itself as Christian but does not take as its starting point the writings of the New Testament, especially the sayings of Jesus as recorded in the Gospels, is difficult to take seriously. Augustine's writings on war, as an example, appeal almost exclusively to the New Testament and within that corpus mostly to the Gospels. So the purpose of this section is first to review those teachings that have served as the starting points for divergent nonideal approaches to warfare (and political life generally), and second to begin to sketch the logic of the contrasting pacifist and just war positions as they attempt to remain faithful to biblical 
teaching. Here there will be no more than a sketch of those nonideal positions, because they are developed more fully in Part V in relation to the ideal theory of a just peace developed in Part IV. But a sketch of the biblical sources and the traditions to which they have given rise is necessary before asking in what relationship, if any, they stand to ideal theory.

"Pacifism is popular": so Nigel Biggar opens the first chapter of his book In Defence of War, and by situating just war primarily as an alternative to pacifism, Biggar stands with many in the mainstream of the tradition that finds its genesis in the writings of Augustine. ${ }^{12}$ The argument that, in light of Christ's command to love one's enemies, warfare is either absolutely prohibited, or at least prohibited for Christians even if accepted as a sad or necessary feature of the world at large, has been made from very early on. ${ }^{13}$ Biggar's worry about pacifism is twofold: it presents an important theological challenge and it represents an unfortunate cultural phenomenon, an inability to distinguish between the "undoubted evils" of war, which may nevertheless be justified, and "its sheer wickedness", which may not. ${ }^{14}$ Biggar's concern about the cultural inability to distinguish between evils is a serious one, about which more will be said in Part V. The focus here is on the theological challenge and its biblical roots, and one does not have to look very far to find them. Matthew's gospel is the primary source for the hard sayings from which pacifist arguments arise, most famously the passage on non-retaliation found in the 'Sermon on the Mount':

You have heard that it was said, 'An eye for an eye and a tooth for a tooth.' But I say to you: Do not resist an evildoer. But if anyone strikes you on the right cheek, turn the other also; and if anyone

\footnotetext{
12 Nigel Biggar, In Defence of War, Oxford University Press 2013, 16. While Biggar argues against other challenges to the just war tradition, pacifism is arguably his primary target; see, e.g., his Introduction and Chapter 1, "Against Christian pacifism". For Augustine's writings on war, see The Political Writings of St. Augustine, Chicago: Regnery Gateway 1962, 162-183.

13 The reasons given by pre-Augustinian Christians like Tertullian for prohibiting Christian participation in warfare were not limited to concerns about homicide; avoiding emperor worship was a major concern; see, e.g., Tertullian's The Military Chaplet and On Idolatry; but the concern about homicide was an substantial one, and that is the concern in view here.

${ }_{14}$ Biggar, In Defence of War, 16: "In much of the West, and especially in Western Europe, war's undoubted evils are barely distinguished from its sheer wickedness". Hereafter references will be made parenthetically within the text.
} 
wants to sue you and take your coat, give your cloak as well; and if anyone forces you to go one mile, go also the second mile. ${ }^{15}$

Immediately thereafter and closely related is the command to love one's enemies:

You have heard that it was said, 'You shall love your neighbor and hate your enemy.' But I say to you: Love your enemies and pray for those who persecute you, so that you may be children of our Father in heaven, for he makes his sun rise on the evil and on the good, and sends rain on the righteous and on the unrighteous. (Matthew 5:43-45)

It is important to see that Jesus' command to his followers to love their enemies is a critical marker of identification with God's own character and activity. Pacifists sensibly link the saying about loving one's enemies to the sayings about non-retaliation. Based on that link as well as on Jesus' own pattern of behavior in Matthew's gospel—e.g., his rebuke of a disciple during his arrest at Gethsemane, "for all who take the sword will perish by the sword" (Matthew 26:52b), and of course his non-resistance to trial and crucifixion-pacifists tend to generalize the love command into an ethic that prohibits retaliatory violence, which seemingly obviously precludes war.

The New Testament's teachings on Christian behavior that have been used to support the pacifist argument, that evil should not be repaid with further evil, are not limited to Matthew's gospel. Paul says much the same in a memorable passage to the Romans:

Let love be genuine; hate what is evil, hold fast to what is good....Bless those who persecute you, bless and do not curse them....Do not repay anyone evil for evil, but take thought for what is noble in the sight of all. If it is possible, so far as it depends on you, live peaceably with all. Beloved, never avenge yourselves, but leave room for the wrath of God; for it is written, "Vengeance is mine, I will repay, says the Lord." No, "if your enemies are hungry, feed them; if they are thirsty, give them something to drink; for by doing this you will heap burning coals on their heads." Do not be overcome with evil, but overcome evil with good. (Romans 12:9, 14, 17-21)

The echoes of the love command are evident in this passage ("bless those who persecute you, bless and do not curse them"), but there is an additional note of waiting for God's

15 Matthew 5:38-41. All biblical quotations taken from the New Revised Standard Version, National Council of Churches of Christ, 1989. Hereafter biblical references will be made parenthetically within the text. 
judgment as well. How Paul sees that judgment being executed, at least in the short run, he

sets forth in the next passage, a discourse on the use of the sword by temporal authorities:

Let every person be subject to the governing authorities; for there is no authority except from God, and those authorities that exist have been instituted by God. Therefore whoever resists authority resists what God has appointed, and those who resist will incur judgment. For rulers are not a terror to good conduct, but to bad. Do you wish to have no fear of the authority? Then do what is good, and you will receive its approval; for it is God's servant for your good. But if you do what is wrong, you should be afraid, for the authority does not bear the sword in vain! It is the servant of God to execute wrath on the wrongdoer. (Romans 13:1-4)

It is important to read Paul's teaching on the authorities in the context of the passage that precedes it, whose injunctions are similar to those in Matthew, and also to remember that for Jesus, loving one's enemies was a mark of identification with God's character and activity.

Very similar teaching is found in the first epistle traditionally attributed to Peter:

For the Lord's sake accept the authority of every human institution, whether of the emperor as supreme, or of governors, as sent by him to punish those who do wrong and to praise those who do right....As servants of God, live as free people, yet do not use your freedom as a pretext for evil. Honor everyone. Love the family of believers. Fear God. Honor the emperor.

Slaves, accept the authority of your masters with all deference, not only those who are kind and gentle but also those who are harsh. For it is a credit to you if, being aware of God, you endure pain while suffering unjustly. If you endure when you are beaten for doing wrong, what credit is that? But if you endure when you do right and suffer for it, you have God's approval. For to this you have been called, because Christ also suffered for you, leaving you an example, so that you should follow in his steps. ...When he was abused, he did not return abuse; when he suffered, he did not threaten; but he entrusted himself to the one who judges justly. (1 Peter 2:13-14, 16-17, 18-21, 23)

According to these apostolic teachings, a place for God's punitive action against evildoers remains alongside Jesus' command to love one's enemies and the dominical and apostolic directives to Christians to do good in the face of evil, even if it means suffering injustice. The standard pacifist accounting for this is to distinguish the duties of a Christian from the duties of the temporal authorities, saying that Paul's command to Christians is embodied in Romans 12, and that while the sword of Romans 13 is ordained by God for temporal purposes, its use is prohibited to Christians. Thus a dualism is established in pacifist thought between the Christian community and the world. Pacifists also point to an event of Jesus' 
own life recorded in Matthew 4 -his rejection of the devil's temptation to rule in splendor over all the kingdoms of the world-as evidence of his rejection of temporal power and as establishing the authoritative pattern for his followers, further cementing that dualism.

If we grant for a moment that these readings of the primary biblical sources are fairly accurate- that Jesus did establish a norm of non-retaliatory suffering in the face of injustice as an expression of God's love, that the apostles continued to enjoin that norm upon the early Christian church, and that the apostles, at least in their contemporary context, saw an important distinction between the vocation of the church and the vocation of the temporal authorities - theological, ethical, and practical issues of consistency and coherence still arise for the pacifist position. Before addressing those issues, however, a point about the use of biblical sources needs to be made. By going beyond Matthew's gospel to other biblical sources of war-related moral commitment, I have taken a canonical view of the New Testament. Obviously this means that the meaning of the teachings of the various sources, at least as it bears on the life of the Christian church, is not limited to the intention of any one author, but that is the 'messiness' that inevitably results from taking a canonical approach. If the canon were limited to Matthew's gospel—and a hermeneutic of selectivity might lead some to circumscribe the canon in exactly this way-pacifists might not have to face the difficult issue of reconciling temporal authority to God's design. But even that is not certain, as will hopefully be made clear below. In any case, I will proceed by treating all of the sources quoted thus far as canonical.

An immediate ethical and practical objection to the pacifist position is that the pacifist relies in practice upon what he contradicts in principle; i.e., the use of the sword to maintain peace. Nigel Biggar puts the objection as follows: If the "peaceable kingdom" that 
pacifists seek to instantiate among themselves were a practicable ideal, then presumably God would have ordained it rather than the "coercive kingdom" described in Romans 13; to the extent that pacifists live out their moral ideal by relying on a peace won by coercion, they act parasitically rather than morally, "keeping their own hands clean only because others are required to get theirs dirty" (43). Whether this is a compelling ethical argument against any given pacifist community depends on the historical circumstances of that community. There are doubtless many pacifists, probably most modern pacifists, who do enjoy and take for granted the peace that is partly maintained through coercion or at least the threat of coercion that pervades modern political societies. However, there are doubtless pacifist communities, both historical and modern, who would have been willing to suffer rapacious activity for the sake of what they counted as faithfulness to Christ, and for whom the temporal authorities were more likely to be rapacious aggressors than protectors of their peace and prosperity. The question of the relationship between political coercion and the order that is necessary for a reasonably peaceful existence is a complicated one and is beyond the scope of this paper. Certainly there is a question of ethical coherence in the pacifist position, but even if it is resolvable in some situations, a deeper question of theological coherence remains.

Recall that Paul described the temporal authorities as instituted by God to "execute wrath on the wrongdoer" and Peter described them as sent by God "to punish those who do wrong", and that both authors situated this teaching in the context of other teaching that amplified the dominical command to love one's enemies. Moreover, recall that for Jesus, loving one's enemies was a mark of identification with God's character and activity: "Love your enemies and pray for those who persecute you, so that you may be children of our Father in heaven". If God is acting through the temporal authorities, at least some of the 
time, to punish wrongdoing, and if our love for our enemies is intended to be emblematic of God's love, then it cannot be the case that loving one's enemy rules out punitive violence altogether, and therefore the initial pacifist generalization, that the love command prohibits retaliatory violence based on the connection between Matthew 5:39-41 and 44-45, becomes problematic. $^{16}$ One way to resolve this theological incoherence would be to appeal to a mysterious sort of dual intentionality in God's providential governance. At some times and towards some enemies, God shows love, but at other times and against other enemies, God executes wrathful vengeance, and the two kinds of actions remain incompatible even if God somehow does both. Biggar criticized pacifists for keeping their hands clean by requiring others to get theirs dirty. At a theological level, this mysterious dualism in action and motive would mean that God's hands are dirty, even as God's followers are expected to keep their hands clean-to be holy-because that is what it means to be and to love like God.

Without diminishing the importance of holiness, another way to resolve the incoherence, the way that gives rise to the just war tradition, is to distinguish the vengeful, retaliatory violence that Jesus prohibits in Matthew 5:39-41 from the possibility of a punitive violence that names wrongdoing for the evil that it is, lovingly protects the innocent from attack by evildoers, brings justice to those who have been wronged, and loves the enemy by aiming to bring him to repentance, forgiven-ness, and reconciliation. It is important to stress the 'possibility' of such violence, not its likelihood, which suggests why most biblical nonideal guidance seems to prohibit it outright. The wider biblical record, however, suggests that such punitive or reprobative actions, especially actions that approach but fall short of

\footnotetext{
16 Reading Romans 13:1-4 as a descriptive reality, whereby the temporal authorities are always executing wrath upon the wrongdoers, is also highly problematic and virtually impossible to reconcile with reality or other biblical sources, even with a high view of God's providence in history; but even if Paul and Peter meant their teaching as what the temporal authorities ought to be doing and should be respected for doing, it presents a problem of theological coherence for the pacifist position.
} 
actual violence, are indeed expected of humans, not just God. An example of this is found in the account of Jesus' trial in the Gospel of John:

Then the high priest questioned Jesus about his disciples and about his teaching. Jesus answered "I have spoken openly to the world; I have always taught in synagogues and in the temple, where all the Jews come together. I have said nothing in secret. Why do you ask me? Ask those who heard what I said to them; they know what I said." When he had said this, one of the police standing nearby struck Jesus on the face, saying, "Is that how you answer the high priest?" Jesus answered, "If I have spoken wrongly, testify to the wrong. But if I have spoken rightly, why do you strike me?" (John 18:19-23)

This passage, being an account of Jesus' own action, may not have the direct force of his teachings about non-retaliation in Matthew's gospel, and as mentioned above in relation to the issue of canonicity, it comes from an altogether different source. However, taking it as a canonical account of his action, what seems very clear is that Jesus' response is a rebuke of the official who struck him, and by extension of the high priest. Combing this account with the aforementioned verse from Peter's epistle-

When he was abused, he did not return abuse; when he suffered, he did not threaten; but he entrusted himself to the one who judges justly. (1 Peter 2:23)

—as well as the sayings about non-retaliation in Matthew 5, the quest for consistency and coherence strongly suggests a distinction between retaliatory and reprobative behavior. Jesus did not fail to entrust himself to "the one who judges justly", but he was willing to speak as one who knew right and wrong, and who was authorized to rebuke wrongdoing. Further evidence for the distinction — as well as for the intention that this distinction would be put into action by Jesus' disciples and not just Jesus himself - is in the verse that serves as the background to Jesus' well-known summary of the greatest commandment:

'You shall love the Lord your God with all your heart, and with all your soul, and with all your mind.' This is the greatest and first commandment. And a second is like it: 'You shall love your neighbor as yourself.' On these two commandments hang all the law and the prophets. (Matthew 22:37-40)

The verse that stands behind the second of these two love commands is from the Hebrew Bible, and it suggests that proper love for one's neighbor includes an element of justice: 
You shall not hate in your heart anyone of your kin; you shall reprove your neighbor, or you will incur guilt yourself. You shall not take vengeance or bear a grudge against any of your people, but you shall love your neighbor as yourself: I am the LORD. (Leviticus 19:17-18, italics added)

If one's neighbor happens to be an enemy, in the sense of having done wrong to oneself or to someone else, loving that neighbor includes reproving him and aiming him at repentance.

Augustine takes this approach in Ad Bonifacem, where he enjoins a "single-minded love" toward the enemy, even while treating him with "an unpleasant severity". ${ }^{17}$ And the just war tradition has followed Augustine in nuancing the pacifist link between the love command and non-retaliation in just this way, by distinguishing retaliatory from punitive violence, and rejecting the pacifist dualism as theologically incoherent, because if loving one's enemies is an aspect of God's character, and if God ordains the use of punitive violence by temporal authorities, then coherence demands that we understand the use of such violence as somehow encompassed within the love command. One way to aim the wrongdoer at repentance is by non-retaliation, but the just warrior resists generalizing this as the only way. Severe as it may seem, the just war tradition holds that stopping a wrongdoer from sufficiently grave evil, even by lethal force as a last resort, is the loving thing to do, an adaptation of the love command to the unfortunate realities of a world where the innocent need protection and violent wrongdoers need to be reproved and resisted.

Even if the distinction between retaliatory and punitive violence is accepted, there remains important line between violence and lethal force. If loving the enemy is aiming him at repentance, lethal force removes that possibility and confronts the Christian with the necessity of weighing the serious theological consequences. But an absolute prohibition on

\footnotetext{
17 Biggar, In Defence of War, 155: “П]n [Augustine’s] letter, Ad Marcellinum (138), after arguing that Christians should eschew the passion for revenge and intend to persuade the wrongdoer to repent and embrace peace, he then articulates what this implies: namely, that just war is waged out of a benevolent concern for the interests of the unjust enemy."
} 
lethal force still raises issues of theological coherence and potentially comes into conflict with love for the innocent neighbor. In any case, it seems that drawing the line between rebuke, non-lethal punitive violence, and lethal punitive violence is nonideal and contestable, unlike the absolute line between loving one's enemies and vengeful retaliation.

The preceding description of the biblical sources from which the pacifist argument arises, and from which it is challenged, obviously does not adequately represent its historical, exegetical, or theological complexity, nor does it aim to do so. My intention has been to illustrate how the hard sayings about non-retaliation, loving one's enemies, and being willing to suffer injustice rather naturally give rise to the generalized pacifist prohibition of war for Christians, how that prohibition runs into issues of ethical and theological coherence in light of other biblical sources, and finally how a quest for coherence suggests a distinction be made between retaliatory and punitive or reprobative violence. More will be said about these distinctions in Part V, but in bringing this section to a close, two final points need to be made: First, both the pacifist generalization and the challenge to its theological coherence take seriously the necessity of instantiating the love command in Christian practice. Any ideal theory that neglected the incorporation of the love command would hardly qualify as a proper aimed-for or regulative ideal for either nonideal pacifism or just war theory. Second, the focus of each approach is on the application of the love command to nonideal circumstances, and no particular nonideal situation-i.e., should one suffer quietly, rebuke one's enemies, or even employ violence against them? - is settled by the debate over coherence. It is only when the pacifist generalization is conceived of as an absolute rule that coherence becomes a challenge, and that challenge highlights, or so I will argue, the need for a more thorough conception of the distinction between prima facie and absolute obligations. 


\section{Moral Commitments in Terms of Prima-Facie Obligations}

The just war tradition arguably arose from the tension between apparently pacifist injunctions in the biblical sources and the challenge of coherence that presents itself once those injunctions are generalized and made absolute. One way to express that incoherence is in terms of the problem of 'dirty hands'. Either, as Biggar put it, Christians are able to keep their hands clean only because others, including God, are forced to get theirs dirty, or there may be times when Christians have to get their own hands dirty in dealing with the evils of nonideal realities. If the dualism of the former, dividing Christians from the world or even from God, is rejected as unacceptable, does that mean the latter is the only alternative? Must we think that reprobative or punitive justice necessarily results in dirty hands? Or is what one's hands do morally neutral, while only one's intentions count as moral or immoral? The answer depends on how the relationship between the biblical injunctions-particularly the command to love one's enemies—and punitive violence against wrongdoers is conceived.

There is some ambiguity in Augustine on this point. It is clear, as illustrated by his teachings quoted above, that Augustine believed that treating an enemy with "unpleasant severity" could be an act of love, but when he says,

What is the evil in war? Is it the death of some who will soon die in any case, that others may live in peaceful subjection? This is mere cowardly dislike, not any religious feeling. ${ }^{18}$

It is not clear that there is anything inherently regrettable about the taking of life in war, as long as it is an instance of loving one's enemy. In some accounts of justified war, which generalize directly from the command to love one's neighbor, the regrettable violence done to and possible death of the enemy fades further from view. See, for example, the following passage by the $20^{\text {th }}$ century Christian ethicist Paul Ramsey:

18 Contra Faustum, XXII, from The Political Writings of St. Augustine, Chicago: Regnery Gateway 1962, 164. 
The Western theory of the just war originated, not primarily from considerations of abstract or 'natural' justice, but from the interior of the ethics of Christian love, or what John XXIII termed "social charity". It was a work of charity for the Good Samaritan to give help to the man who fell among thieves. But one step more, it may have been a work of charity for the innkeeper to hold himself ready to receive beaten and wounded men, and for him to have conducted his business so that he was solvent enough to extend credit to the Good Samaritan. By another step it would have been a work of charity, and not of justice alone, to maintain and serve in a police patrol on the Jericho road to prevent such things from happening. By yet another step, it might well be a work of charity to resist, by force of arms, any external aggression against the social order that maintains the police patrol along the road to Jericho. This means that, where the enforcement of an ordered community is not effectively present, it may be a work of justice and a work of social charity to resort to other available and effective means of resisting injustice: what do you think Jesus would have made the Samaritan do if he had come upon the scene while the robbers were still at their fell work ${ }^{19}$

Ramsey is clearly not doing a work of exegesis, which he explicitly acknowledges (62). But the way he retells the story of the Samaritan shifts the attention away from individual action and intention-which were the objects of Jesus' teaching in response to the lawyer's question, "Who is my neighbor?"-and poses instead the question of how the love command would express itself in the ordering of society for the common good. His primary concern is to demonstrate that the logic of loving one's neighbor does not end with what we usually call charity, but extends into the realm of justice; and while he maintains a distinction between charity and justice, Ramsey contends that our conceptions of justice have already been transformed by the Christian love ethic to a greater extent than we realize.

The tradition of just war in view here is focused on the common good of the social order as a logical outgrowth of the command to love one's neighbor, not specifically on how loving one's enemy can take the form of punitive violence. Ramsey is not alone or novel in commending this view of the just war tradition, as Augustine, Aquinas and others have put a high value on the social order. And even apart from the preservation of it, protection of the innocent is certainly an expression of love, and perhaps the primary criticism of nonideal pacifism is its failure to make provision for the protection of the innocent. But a potentially

\footnotetext{
${ }_{19}^{19}$ Paul Ramsey, The Essential Paul Ramsey: A Collection, New Haven: Yale University Press 1994, 62.
} 
serious problem with Ramsey's account is that by making just war a straightforward outcome of the love command, it risks losing sight of the problematic nature of punitive violence. Even if we distinguish retaliatory and punitive violence, the first being plainly incompatible with biblical teaching, and the second being not only compatible, but perhaps necessary to avoid theological and ethical incoherence, how should we understand that compatibility? It seems wrong to see punitive violence, or even rebuke, as loving in the normal sense, e.g., in the same way as giving gifts to one's loved ones or as God sending rain on the just and the unjust alike. So if it is loving, and if it must be absolutely distinguished from non-loving retaliatory behavior, how does it also need to be distinguished from loving behavior that is not as obviously problematic? ${ }^{20}$ Fortunately there is such a distinction, which is the subject of this section and which also relates to the move from ideal to nonideal theory.

In a seminal article on the interrelationship between just war theory criteria, James Childress uses the concept of prima-facie obligations to illuminate those criteria and explain the family resemblance of just war theory to other theories that also seek to justify violence or political resistance. ${ }^{21}$ Childress makes the point that we use criteria that are analogous to those used to determine whether a war is justified (e.g., just cause, right intention, last resort, reasonable hope of success, balance between good ends and moral costs, etc.) whenever we face situations where it would be impossible to fulfil all of the obligations that we face (429). The obligations that Childress has in mind are those that we would normally think of in terms of respecting the rights of others or fulfilling duties attached to our particular vocations and relationships. One such obligation, although it is by no means the only one

\footnotetext{
${ }^{20}$ None of this is intended to say that the 'normal' ways we love one another-e.g., through gift giving—are immune from being morally problematic. But giving a gift is given the benefit of the doubt in a way that violence is not, and rightly so.

${ }^{21}$ James Childress, "Just-War Theories: The Bases, Interrelations, Priorities, and Functions of their Criteria", Theological Studies, Vol. 39, No. 3, September 1978, pp. 427-445.
} 
that would put us in a situation where we needed to justify our actions, is the obligation not to injure or kill others. If injury means an "unwarranted or unjustified harm or violation of rights", then not injuring others is an absolute obligation, because to injure them unjustifiably is "wrong by definition" (430). But does that mean that a justifiable injury (e.g., a doctor who re-breaks a child's arm in order for it to heal correctly) is unproblematic, 'morally neutral', or not wrong in any meaningful sense? Following W. D. Ross and William Frankena, Childress says no; such an act may not be absolutely wrong, but it is prima-facie, or “intrinsically" wrong (431). Breaking a child's arm is not morally neutral. It is intrinsically wrong, even if not absolutely wrong, as in the case described, where it is being done for the child's good by a competent authority. And its intrinsic or prima-facie wrongness shows up in two ways: First, such acts must be justified, usually using criteria that closely resemble the criteria used to justify going to war: Is there a just cause (e.g., the healing of the child's arm)? Is it done by a competent authority (e.g., the doctor)? Is it the last resort, or is there better way? Second, acts that are prima-facie wrong leave moral traces that morally unproblematic acts do not, which requires further care by the authority: Was the doctor gentle with the child, and did she do what she could to minimize suffering? Did she or the attending parent say they were sorry that it had to be done and regret having to do it? How Childress applies the concept of intrinsic wrongness to the just war criteria will be revisited in Part V; two further applications of his analysis need to be considered before turning to ideal theory.

First, we can apply the distinction between absolutely and intrinsically wrong acts to the biblical injunctions canvassed above, to clarify the injunctions and also the part that they would play in specifying moral permissibility for nonideal theory. Childress applies the distinction to the prohibition on killing/murder in the Hebrew Bible: 
If the Fifth (or Sixth) Commandment means "Thou shalt not kill", it is prima-facie rather than absolute; for the Hebrews admitted killing in self-defense, capital punishment, and war. If it means "Thou shalt not commit murder," it can be taken as absolute, but it leaves open the question which killings are to be counted as murder. (431)

If a commandment is stated as an absolute, it leaves the nonideal challenge of deciding when it applies. If it is stated in broadly general terms, then it is best understood as prima-facie if exceptions to it are admitted as morally legitimate in practice. Clearly there are commands that Christians take to be absolute, such as the 'greatest commandment', to love God, and the 'one like it', to love one's neighbor as oneself. Presumably the command to love one's enemy is taken to be absolute as well. The nonideal approaches diverge with regard to the command to turn the other cheek. The pacifist tradition takes it to be an injunction against all forms of violence and takes it to be absolute. The just war tradition, at least in its most well-developed forms, distinguishes between vengeful retaliation and punitive violence; the injunction against the former is absolute, but the injunction against violence generally is a prima-facie obligation, not an absolute one. The pacifist insistence on an absolute command against violence leads to the problems of ethical and theological coherence described above, which the just war tradition tries to avoid. But what the traditions have in common is a view of violence as intrinsically wrong, which at the very least needs to be justified.

What about the issue of 'dirty hands' for the just war tradition? Clearly the tradition seeks to avoid the dualism that leaves others, including God, to get their hands dirty through absolute wrongdoing in order for some to remain clean. But with an understanding of primafacie wrongness, the problem of 'dirty hands' does not disappear entirely, as it would if somehow a loving intent wiped away any morally traces of intrinsically wrong actions, or as if those acts were themselves morally neutral. The just warrior's hands are not dirty in the same way as the hands of a murderer, but they are dirty in that a moral trace attaches to 
them, and Childress identifies this with the feeling of regret (if not necessarily remorse). ${ }^{22}$

The tradition is not unanimous on this point, but at least some parts of it acknowledge the moral traces that remain, and the sorrow and regret that ought to accompany them. For the pacific ideal's regulation of moral permissibility, the absolute obligations that arise from the biblical injunctions-e.g., loving one’s enemy and not engaging in vengeful retaliation-will remain in force for nonideal circumstances, and the moral costs that arise from violating prima facie obligations will have to be taken into account in deciding on nonideal policy.

Second, the force of the absolute and prima-facie obligations in regulating the moral permissibility of acts within war depends on a certain level of moral continuity between peace and war. Childress describes this continuity—and discontinuity-eloquently: War and politics, or peace, are not two totally separate realms, or periods. Both are subject to moral
principles and rules, and, indeed, to many of the same principles and rules. War ought to fall within
many of the same boundaries that are also important in peace.

Theorists and practitioners are commonly tempted to make war merely an extension of politics, so that it requires very little to justify waging war; or they are tempted to make politics and war so discontinuous that once one enters the state of war, previously important moral, political, and legal considerations become irrelevant. Two points need to be affirmed. On the one hand, war must be justified because it violates some of our prima-facie obligations, not because it is totally immoral or amoral or utterly discontinuous with politics; on the other hand, it can be more or less humane insofar as it is conducted in accord with some standards that derive from the overridden prima-facie obligations and other obligations that endure even in war. Furthermore, however much continuity there is between peace and war, peace remains the ultimate aim of a just war. (433-34) (italics mine)

There is an important and irreducible difference between peace and war, and for that reason the jus ad bellum remains indispensable. That difference, however, is not equivalent to the difference between morality and amorality or immorality. (434-35)

The break between peace and war and peace again is not so radical as to make the norms of

peace irrelevant to the morality of war, and yet peace and war are discontinuous enough for war to require a grave violation of the just peace in order to be justified. The pacific norms will remain present in the form of both absolute and prima-facie obligations.

22 Childress highlights a difference between some Protestant and Catholic interpreters of the just war tradition: the former view war as a "the lesser of two evils", which should occasion both regret and remorse, while the latter view it "the lesser of two goods", which can occasion regret but not remorse. Either way, at least regret as a moral trace remains (432). 
Finally, Childress holds it to be unnecessary to identify the source of the prima-facie obligation not to kill or injure others and simply states that it is "compatible with a number of philosophical and religious frameworks" (431). Since one of the aims of this paper is to determine the relevance of just peace as an ideal for Christian ethics, it is unnecessary to seek further sources for the obligation beyond the ones already identified. But it is interesting to ask — in light of the love command and the other hard sayings—if injuring or killing others is not absolutely prohibited, how is it that it is intrinsically prohibited? One way to answer that question is to say that it is not the way things ought to be; or put another way, it is not how things would be ideally. And that ideal is relevant not only in what we ought to be aiming for, but in the traces it leaves or the shadow it casts over our nonideal reality. How it casts that shadow, or the continuity that remains between peace and war, I will discuss in the next section, along with the development of just peace as ideal theory.

\section{Just Peace as Ideal Theory}

We now come to the primary goal of my thesis, which is to articulate just peace as an ideal theory, anticipating the relationship in which it will stand to nonideal ethics of conflict, such as just war theory and pacifism. Clearly this pacific ideal will have to incorporate the moral commitments discussed in the last two sections, but it will also need to be developed with two aspects of the relationship between ideal and nonideal theory that Simmons articulated in mind: First, the pacific ideal must represent a 'realistic' ideal. Second, it must not only represent a goal to be aimed at by politically possible and likely effective means, but also serve as a guide to what is morally permissible.

It is a commonplace in the just war tradition that the proper aim of - and intention behind-a justified war is peace, and this goes back to Augustine: 
Peace should be the object of your desire; war should be waged only as a necessity, and waged only that God may by it deliver men from the necessity and preserve them in peace. For peace is not sought in order to the kindling of war, but war is waged in order that peace may be obtained. Therefore, even in waging war, cherish the spirit of a peacemaker, that, by conquering those whom you attack, you may lead them back to the advantage of peace; for our Lord says: "Blessed are the peacemakers; for they shall be called the children of God."23

Augustine does not seem concerned with asking whether a just peace is realistic or how exactly the just peace might regulate the conduct of war beyond ordering the intentions of those who wage it. However, the idea that peace is not only the aim of a justified war, but also plays an important role in disciplining the use of force is now also a commonplace in the just war tradition. Recall Biggar's criticism of pacifists for relying in practice on what they contradicted in principle. What he says afterwards - relating the idea of the "peaceable kingdom" to the just war tradition—-is revealing:

Instead of this incoherent view, one might regard the non-coercive, entirely God-ordained society not as a current alternative to one where the public use of force is ordained, but rather as its ideal goal. Thus the pacific ideal would so function as to qualify and discipline the current use of force, which ultimately intends it. Rather than produce two distinct classes of people-those who use the sword, and those who point to peace-it would produce one class only-those who struggle to use the sword pacifically. This, however, would bring us not to pacifism, but to the doctrine of just war. (43) (italics mine)

Rather than rejecting the "pacific ideal" for being unrealistic, Biggar praises it as both the aim of and the qualifying and disciplining basis for the nonideal use of violent force. A justified war is a nonideal policy aimed at the pacific ideal, regrettably necessary due to partial compliance with that ideal, and only a rightly-intended, lovingly-executed war in response to injustice, aimed at securing the ideal of just peace, is justifiable as a nonideal policy (155).

The critical move that enables peace to function not only as the rightly-intended aim of war but also as its limiting ideal is the specification of a just peace. After all, one could aim with sincere intentions at the complete annihilation of one's enemy and call it peace, and it might be more stable than a just peace. Such a peace would, of course, make a mockery of

23 Ad Bonifacem, CLXXXIX, from The Political Writings of St. Augustine, Chicago: Regnery Gateway 1962, 182. 
the pacific ideal, but that is because the pacific ideal retains its relevance in nonideal reality with regard to moral permissibility. What this requires is the moral continuity between peace and war described above. As discussed in the previous section, Childress speaks of the standards that continue to govern the conduct of war in terms of the prima-facie obligations that leave moral traces even when they are justifiably overridden. But as we saw with the biblical sources of moral commitment that divide Christians on the issue of war, some moral obligations are considered to be prima-facie and others retain their absolute character. The continuity between peace and war and the distinction between absolute and prima facie obligations allows us to see how the pacific ideal will regulate what is morally permissible in nonideal policy_by continuing to prohibit what is absolutely prohibited and by weighing the moral costs of violating what is intrinsically prohibited. Clearly the sort of peace that is aimed at influences the kind of war that is fought. What remains is to specify the content of the pacific ideal and describe how it could serve as a 'realistic' ideal.

The obvious place to begin is with Jesus' command to love one's enemies, which we can take to be a further specification of his command to love one's neighbor, revealing the extent of the latter's application if not its actual content. Its content is partly specified in the prohibition on retaliatory violence, returning evil for evil in the sense of getting even. There are problems of biblical consistency and theological and ethical coherence in generalizing the prohibition to exclude all forms of violence in the name of justice, much less reproof and rebuke, which may stop short of physical violence. Therefore, it may be that love does not absolutely prohibit seeking justice through punitive action, up to and including violence, but does it actually entail justice? Does the love command direct us to a peace that embodies justice? And however we might answer that, what impact does the love command have on 
how we conceive of justice? Articulating an account of just peace that is true to the biblical vision requires taking some sort of stand on the relation between love and justice.

A tradition of thought, sometimes called the 'agapist' tradition, has developed out of reflection on the love command and what it means for Christian ethical life. It began in the $19^{\text {th }}$ century with Soren Kierkegaard's Works of Love and was developed in the $20^{\text {th }}$ by writers such as Anders Nygren, Reinhold Niebuhr, and Paul Ramsey, and contemporaries such as Linda Woodhead, Timothy Jackson, and Nicholas Wolterstorff. I will draw briefly on Niebuhr, Ramsey, and Wolterstorff to articulate how we may think of the relationship between love and justice and how it would impact the content of the pacific ideal.

Niebuhr's engaging conception of the love command and its relevance for human ethical life is grounded in his anthropology. ${ }^{24}$ For Niebuhr, humans are radically free in their capacity for transcendence, not only of the systems of justice and order to which they are subject, or of the systems of reason that purport to explain the realities they inhabit, but also of their own matrices of desires and agendas, which they can call into question. Yet they are also finite in their embodiment and mortality—not in themselves evils—and they are sinful in their refusal to accept their finiteness and trust God for their security and their destiny. According to Niebuhr, the only 'law' that is adequate to address humans in their radical freedom is the law of love, and yet due to their sin-stained finiteness, it is an impossible ideal, an 'impossible possibility'. In his criticism of pacifism, Niebuhr writes:

The pacifists are quite right in one emphasis. They are right in asserting that love is really the law of life. It is not some ultimate possibility that has nothing to do with human history. The freedom of man, his transcendence over the limitations of nature and over all historical and traditional social situations, makes any form of human community which falls short of the law of love less than the

${ }^{24}$ For the source of the following description of Niebuhr's anthropology, see The Nature and Destiny of Man: A Christian Interpretation, Louisville, KY: Westminster John Knox Press 1996, pp. 150, 163-166, 175-179. 
best....The law of love therefore remains a principle of criticism over all forms of community in which elements of coercion and conflict destroy the highest type of fellowship. ${ }^{25}$

The law of love, which is the "law of life", is not merely an impossible ideal, but a principle of criticism against which all human forms of fellowship are measured and found wanting. Niebuhr's conception of what the love command entails is radical self-sacrifice, exemplified by Jesus' death on the cross. Such love, in Niebuhr's view, entails not only non-violent resistance, but seemingly a pure and complete non-resistance in the face of evil.

Justice for Niebuhr, by contrast, is the messy but delicate balancing of interests in a world of self-centered, sinful human relationships. In the same way that human finiteness is not itself evil, neither is justice, but because of sin, human attempts at justice are perpetually subject to the criticism, made possible by human freedom, of the law of love.

The ultimate principles of the Kingdom of God are never irrelevant to any problem of justice, and they hover over every social situation as an ideal possibility; but that does not mean that they can be made into simple alternatives for the present schemes of relative justice. (25)

Yet Niebuhr does not counsel complete non-resistance in the face of evil or abandoning attempts at justice just because all such attempts or resistance will fall short of the law of love. On the contrary, he contends that Christians are bound to pursue justice just as they are bound to accept their own finiteness, but they are to do so without illusions. Moreover, the law of love plays a role in discriminating between various attempts at justice:

The recognition of the law of love as an indiscriminate principle of criticism over all attempts at social and international justice is actually a resource of justice, for it prevents the pride, self-righteousness, and vindictiveness of men from corrupting their efforts at justice. But it must be recognized that love is also a principle of discriminate criticism between...various attempts at justice. (25-26)

It is not clear whether love motivates justice, but it is not, after all, completely divorced from justice. Love transcends justice but still relates to it dialectically, serving not only to judge the shortcomings of justice but to discriminate between better and worse attempts at it.

${ }^{25}$ Reinhold Niebuhr, "Why the Christian Church is not Pacifist", Christianity and Power Politics, Charles Scribner 1940, 21-22. 
Here we have the makings of an ideal-nonideal theory that purports to incorporate the sources of Christian ethical commitment and deal squarely with the realities of nonideal circumstances. It is not of the Rawlsian variety, to be sure, as the ethical commitments of its ideal theory are not derived by a hypothetical social contract, but rather from a transcendent source. The problem is not that Niebuhr's source of ethical obligation is heteronomous, strictly speaking, because Niebuhr claims an anthropological basis for that transcendence, and in any case, the point here is not to meet Rawls's standards for what counts as an adequate ideal theory in terms of form or content. The problem is whether a Niebuhrian account of a just peace could serve as a proper ideal for nonideal theory along the Rawlsian lines that Simmons reconstructs: Is it sufficiently realistic? And does it provide the guidance that is needed to deal with questions of moral permissibility in nonideal policy?

I will take up the question of how an ideal theory based on the love command could be realistic shortly. As for whether Niebuhr's provides sufficient guidance, the answer is almost certainly no, because the Niebuhrian account not only leaves it unclear whether love actually motivates justice, but it also underdetermines how love is to limit attempts at justice. The traces of continuity between peace and war and peace again that Childress articulates are difficult if not impossible to account for in Niebuhr's dialectical account. The absolute obligations that are identified with the just peace-e.g., loving one's neighbor as oneself—as well as those that are incomprehensible apart from nonideal circumstances-e.g., loving one's enemies and refraining from vengeful retaliation-do not enter nonideal policy with any force, except to judge it post hoc from a transcendent vantage point, so that moral permissibility in Niebuhr's account is reduced to weighing the moral costs of just as well as unjust violence against the moral gains of the state of tainted justice that one is aiming at. 
Niebuhr would likely have insisted that, however perverse such a calculation may be, it is simply the reality we face. But not all 'realists' agree. Ramsey, writing not long after the height of Niebuhr's influence and considering himself a realist, says the following about how absolute obligations persist in a justified war properly motivated by love for one's neighbor:

\begin{abstract}
The justification of participation in conflict at the same time severely limited war's conduct. What justified also limited! Since it was for the sake of the innocent and helpless of the earth that the Christian first thought himself obliged to make war against an enemy whose objective deeds had to be stopped, since only for their sakes does a Christian justify himself in resisting by any means even an enemy-neighbor, he could never proceed to kill equally innocent people as a means of getting at the enemy's forces. Thus was twin-born the justification of war and the limitation which surrounded noncombatants will moral immunity from direct attack. Thus was twin-born the distinction between combatant and noncombatant in all Christian reflection about the morality of warfare. This is the distinction between legitimate and illegitimate military objectives. (63)

Christian love does not simply hover over the realities of political life, as a vision of how life might be lived otherwise. It incarnates itself in the actualities and provides itself grounds for action by fashioning discriminating judgments between acts of war proposed to be put forth. (82)
\end{abstract}

The advantage of Ramsey's account is twofold: First, it pushes for coherence between the justice we are aiming at and the means we use in aiming at it. If Niebuhr is right in holding that we ought at times to enter the struggle for justice even when we know that our attempts will fall short of what love requires, at the very least our attempts should rule out actions that destroy or undermine the very things we are trying to protect or vindicate. Second, Ramsey preserves the continuity between peace and war and peace again that Childress articulates. The violation of intrinsic obligations that a justified violence entails do not move us into a realm where morality no longer applies or even one where it is only transcendent; on the contrary, moral commitments are still binding, even if some of the prima facie ones must be regrettably violated, in which case those moral costs must be accounted for honestly. As we saw earlier, a potential problem with Ramsey's account was that it insufficiently recognized the lingering traces of violated prima facie obligations. An adequate ideal theory of just peace, if it is to incorporate the moral force of the love command and preserve sufficient continuity 
between just peace and justified conflict, will not regard the love command as an impossible possibility', but will specify its content so that it can regulate nonideal policy. Moreover, the pacific ideal will ground the intrinsic moral status of obligations that may have to be violated, thus making imperative an honest accounting of the moral costs of such violation.

However, all of this presupposes that love not only restrains, but motivates, action in pursuit of a just peace. Niebuhr's conception of agape as purely non-resistant self-sacrifice is problematic, because it underspecifies and hamstrings how love concretely applies to others, especially in a social context where justice is at stake, and even with regards to the enemy. In his extensive review of the modern agapist tradition, Nicholas Wolterstorff attributes the disharmony between love and justice in those writers to a malformed view of love. ${ }^{26}$ The modern agapists, including Niebuhr, almost unanimously took the love that Jesus enjoined to be a purely spontaneous, gratuitous love, indifferent to the value of the other. Such love, in their view, must be blind to justice, because justice, concerned about the value of and with what is due to the other, is not gratuitous. The paradigmatic case of such love is forgiveness, which is granted to the evildoer in spite of what is due to him; forgiveness, on this view, is contrary to justice. Wolterstorff contests this view of love, justice, and forgiveness by noting that without the justice-based concept of being 'wronged', forgiveness as an expression of love is conceptually impossible (54-55). What makes forgiveness possible as an expression of love is that the one who has been wronged value herself enough to recognize that she has been wronged. Certainly love as forgiveness is not required by justice, but it makes sense only against a backdrop of active attention to value and justice, not indifference towards it. Niebuhr, of course, remained actively attentive to justice, but due to his view of the essence

\footnotetext{
${ }^{26}$ See chapters 2-5 of Wolterstorff's Justice in Love (Eerdmans 2011) for his review of the modern agapist tradition.
} 
of agape, he did not see the pursuit of justice as a potential embodiment of love. Wolterstorff further argues that love not only operates against the backdrop of value and justice, but that it actively incorporates justice by seeking to treat others as befits their worth as fellow human beings, and this includes not only seeking to protect and vindicate those who are wronged, but also reproving those who perpetrate wrong (75-77). Wronging others diminishes the humanity of those doing the wrong, because their moral condition is an important aspect of their life's value. Because the love command extends to the enemy, and because reproof of the enemy is necessary and violence against the enemy may be conceivable as an act of love, it is likely to be accused of paternalism. From the standpoint of paternalism, however, the real difference between what is entailed by the love command and what passes for deterrent or retributive justice in most societies is the former's frank insistence that acknowledgment of and repentance for wrongdoing are serious matters of justice. In any case, Wolterstorff defends his position with an appeal to scripture, especially the passage from Leviticus, quoted above, from which Jesus quoted the love command (80-84):

You shall not hate in your heart anyone of your kin; you shall reprove your neighbor, or you will incur guilt yourself. You shall not take vengeance or bear a grudge against any of your people, but you shall love your neighbor as yourself: I am the LORD. (Leviticus 19:17-18, italics added)

If Wolterstorff is correct, then the love command not only entails that we limit our actions in pursuit of justice to what is morally permissible, but that we actively seek just peace. The pacific ideal is not optional for those who accept the obligation of the love command.

There is much more to an ideal theory of justice than a concern that others not be wronged unjustly; by definition, the ideal is one of strict compliance, so being wronged is out of the question when one lives in a state of ideal justice. The content of that state depends upon the theory. For Rawls, it was a state of 'justice as fairness', with egalitarianism as the 
norm unless a departure from it could be justified by benefits that would otherwise be lost accruing to the least well-off member of society (Rawls's famous 'difference principle'). For a Christian, it may be that each person is treated with the reverence that befits their worth as a creature made in God's image. Spelling out whether this would require a sufficientarian, egalitarian, libertarian, or some other principle of distribution is beyond the scope of my thesis. In evaluating Christian ethics of conflict, the crucial point of an ideal theory of just peace is that, in cases of deliberate noncompliance, it guides us towards whatever that ideal state of justice is and limits our conduct to what is morally permissible in light of it.

There is another crucial aspect of the pacific ideal that is likely to distinguish it from many other ideal theories of justice, especially variants of Rawls's theory. The Christian ideal of a just peace is a state of justice among repentant, forgiven, and reconciled wrongdoers. As an aimed-for ideal, it is clearly not an ideal for the innocent. But it is also not an ideal that ignores the past or considers what happened in the past irrelevant for determining whether the society is currently in a state of justice. ${ }^{27}$ It cannot be indifferent to the difficult questions of how state boundaries came to be or how groups of people have been treated unjustly, and those difficulties do not go away simply by virtue of ideal distributive principles being satisfied going forward. Nevertheless, any principle of nonideal rectification would be subject to the same moral permissibility limits as any other nonideal policy.

Finally, there is the question of whether the pacific ideal is realistic in the sense that Simmons articulated as a requirement for an adequate ideal theory. It is certainly no more realistic than the Rawlsian ideal, nor does it need to be in order to serve as a proper ideal. It

\footnotetext{
${ }^{27}$ In this sense, the pacific ideal has something in common with the historically-rooted entitlement theory of justice that Robert Nozick develops in Anarchy, State, and Utopia that it does not with Rawls's ideal theory in A Theory of Justice, although it does not necessarily commit to Nozick's libertarian formulae or reject Rawls's egalitarian ones.
} 
does, however, face a theological difficulty that Rawls's theory does not. The Christian hope of full compliance with the teachings of Jesus has traditionally been conceived of as a hope with an irreducible eschatological element at both the individual and societal level. At the individual level, ultimate deliverance from sin, death, and judgment comes by way of resurrection and glorification in the face-to-face presence of God, and at the societal level, the community of such individuals is the ultimate dwelling place of God. To reduce that hope to the idea of a this-worldly just peace for the sake of a regulative goal in circumstances of conflict would indeed be heretical. On the other hand, to hold out that vision in its fullness as the pacific ideal seems to completely discard any notion whatsoever of a 'realistic' ideal. The danger in the other direction, however, is to treat the biblical injunctions as less serious than they are or as other-worldly ethics with no real relevance to nonideal circumstances. And the option of doing without ideal theory altogether is problematic for reasons already discussed-e.g., both non-violent resistance and justified wars aim at some state of affairs, and there is a moral continuity between states of peace and conflict that is morally relevant to the state of conflict. So we are left to formulate a pacific ideal that is true to its biblical and theological roots and yet serves as a realistic ideal.

I propose to do this by speaking in terms of acknowledgment. By 'ideal' we need not mean a society of sinless persons. On the contrary, humanity would be caught in the same cycle of ignorance, hardheartedness, transgression, culpability, reproof, sorrow, repentance, forgiveness, and reconciliation as they are today. But ideally the acknowledgement of the love command and the effort to live by it among both rulers and citizens would be fairly general; under those circumstances, the unlikelihood of needing to go to war for defensive or punitive reasons, much less aggressive ones, is conceivable. Again, the point here is that 
strict compliance is conceivable, not that it is realistic. What makes it conceivable is that all else is realistic, or perhaps not unrealistic, for "men as they are and laws as they might be". Also, compliance does not mean perfectly loving one's neighbor as oneself; it means treating one's neighbor justly, and when one fails to do that, acknowledging the failure and repenting. In that way, the pacific ideal is not the perfect instantiation of the love command, and the love command is not reducible to a just peace. An important element remains, and rightly so, of Niebuhr's 'impossible possibility', which addresses humans in their transcendence and chastens all of their attempts at love. The pacific ideal is, however, the instantiation of the love command with regard to its demand that people treat one another justly.

\section{Nonideal Theories of Conflict in Light of the Pacific Ideal}

Now is the time to evaluate a variety of nonideal ethical theories of conflict in light of the pacific ideal, most importantly the traditions of pacifism, non-violent resistance, and the just war, and to ask what relevance the pacific ideal has or should have for Christian reasoning about conflict. Before turning to pacifism, however, it is worth considering a variety of views that sometimes fly under the flag of 'realism', but that are worth delineating separately and evaluating in light of what has been discussed so far about the continuity of moral obligation between peace and war and peace again. Unsurprisingly, Childress is eloquent in describing the first of these positions, that of 'war as hell' or 'war as crime':

A model of war as a rule-governed activity stands in sharp contrast to a model of war as hell, which is accepted by most pacifists and by many "realists" who recognize no restraints other than proportionality...According to [this] view, war is hell, murder, and there is thus only the crime of war, within which anything goes, for "all's fair..." According to another view, war is game-like (not in a frivolous sense) or a rule-governed conflict, within which one may legitimately injure, kill, and destroy, but not commit war crimes such as injuring or killing defenseless persons who are noncombatants or excombatants. For the view that war is "total" and without limits, the only critical moral factor is the decision to wage war, and moral blameworthiness may attach to the side starting the war, sometimes even to the side firing the first shot. For the view that war is a rule-governed activity, the jus in bello becomes very important. Any adequate theory, however, should not concede that jus ad bellum is unimportant because some moral principles and rules persist in war. There is an important and 
irreducible difference between peace and war, and for that reason the jus ad bellum remains indispensable. That difference, however, is not equivalent to the difference between morality and amorality or immorality. (434-35) (italics mine, except for jus in bello and jus ad bellum)

Childress uses the classic just war tradition terms jus ad bellum and jus in bello, which refer to the justice of going to war and the just prosecution of a war, respectively. In the model of 'war as hell' that he describes, the decision to go to war is a grave matter to which moral reasoning applies, but once war is underway, perhaps to repel an unjust invasion, no trace of the intrinsic obligations that have been overridden remain; in fact, restraints that might have remained are potentially abandoned even further due to indignation at the unjust enemy.

Another realist model is that of 'war as a game', but not in the sense that Childress uses above to describe the observation of jus in bello; the game here is the game of balance of power, or national interest, or imperial policy. It relies on the idea that morality is simply irrelevant in matters of international relations, and the classic text supporting this position is the Melian Dialogue in Thucydides' History of the Peloponnesian War. In that dialogue, the Athenians threaten the Melians with slavery and destruction if they do not surrender and pay tribute. The Melians reply that the Athenians have no need to conquer them, and that it would be shameful for them to submit to such a demand. The Athenians argue that they are driven by need, the need of appearing strong, that both the strong and the weak act from necessity, and that 'right' is might. In his classic work Just and Unjust Wars, Michael Walzer argues compellingly against the 'realist' position, noting that warmongers rarely speak so candidly as the Athenians; the inescapable moral reality is revealed by the excuses rulers give and the lies that they tell: "They lie in order to justify themselves, and so they describe for us the lineaments of justice". ${ }^{28}$ Ironically, however, the model of 'war as a game', while it

\footnotetext{
${ }^{28}$ Michael Walzer, Just and Unjust Wars, $4^{\text {th }}$ ed., New York: Basic Books, 2006, 8.
} 
completely disregards jus ad bellum, is possibly less of a 'hell' for strategic reasons and the absence of indignation at an unjust enemy. Of course, it is likely to be both. For the despicable Athenian rulers, war was a game, but for the Melians, a hell.

The immorality of these two approaches to war in light of the pacific ideal should be fairly obvious. War as a game is not fought with just peace as its aimed-for ideal, even if it may be cloaked in talk of a just cause. And war as hell, even if it is fought for a just cause, disregards both the regulative aspect of the pacific ideal, rooted in the moral continuity that persists between peace and war, and the moral costs that are sure to subvert the justice of the peace that will follow a war fought with moral abandon. Moreover, both approaches abandon any semblance of consistent obedience to the love command, either by truncating its relevance to times of peace (war as hell) or by relativizing it altogether (war as a game).

There are many Christians, of course, who self-identify as realists, and the spectrum of their views of what constitutes political and social reality varies widely, from Hobbesians at one end to Augustinians like Biggar nearer the other, with Reinhold Niebuhr somewhere in between. ${ }^{29}$ But even for those who accept the Hobbesian view of human psychology (e.g., humans are dominated by egocentrism, competitiveness, fear, etc.), it is a descriptive reality, not a normative one, and one that is decidedly immoral in the light of the love command; it can hardly be used to justify the amorality of international relations. More important than the term 'realist' is the way that any particular Christian realist conceives of the relationship between his moral commitments and the morality of war. Niebuhr is a good example of the importance of the details. He is notable in that he combines a fairly pacifist view of the love command (i.e., that it prohibits punitive violence across the board) with a very sober view of

\footnotetext{
${ }^{29}$ See Biggar, In Defence of War, 9-13. Biggar self-identifies as an Augustinian and repeatedly disavows Hobbesianism.
} 
"the tragic character of the necessity" of war. ${ }^{30}$ In practice, he asked questions very similar to those motivated by the just war tradition: Is the cause just? Are the means necessary, proportional, and not subversive of the end being aimed at? But he limited the criteria of moral permissibility to consequentialist considerations, rejecting any absolute distinctions between conduct that is acceptable (e.g., targeting an enemy soldier) or unacceptable (e.g., targeting civilians) in war. Niebuhr's realism is a valuable perspective for evoking moral regret over the prima facie obligations that are violated in war, but it is inadequate on account of its under-specification of the love command's continued relevance in the context of war.

Most forms of 'realism' do not fare well in light of the pacific ideal, but not because there is something wrong with being 'realistic'. On the contrary, it is an admirable aim and goes a long way towards explaining the appeal of various positions that purport to be realist. But serious advocates of non-violent resistance and justified war also strive to be 'realistic', as we will see below, especially in the case of the criteria employed by the latter. What they preserve that 'realists' often do not is an awareness of the moral reality that pervades the lead up to war and the continuing moral relevance of the norms of peace in the prosecution of war. Nor do these realist positions fare poorly in light of the pacific ideal because the latter is too 'idealistic'; a model of war as a game also has ideals in mind, but they are ideals that Christians should at least be wary of and likely reject as incompatible with the pacific ideal.

The case of pacifism is different, because it is usually assumed that, on its face, there is no important difference between the pacifist position and the pacific ideal. And pacifism is widely rejected by Christians, not because they disagree with the ideal, but because they see

\footnotetext{
${ }^{30}$ For this quote and the discussion that follows it, see Niebuhr's essay "Is the Bombing Necessary?", Christianity and Crisis, Volume IV, No. 5, April 3, 1944, in which he questions the area bombing and unconditional surrender policies of WWII.
} 
it as illusory and unhelpful. If war were unnecessary, it would certainly be unacceptable, as pacifists insist. Presumably all sincere Christians would agree with them. But their response to the pacifist is: "Yes, of course war is horrible, and in an ideal world, there would be no war. But we do not live in an ideal world, don't you see?" The response is understandable, but there are two major problems with it that undermine thoughtful Christian dialogue on how to approach the ethics of conflict: First, there are potentially very important differences and incompatibilities between any given pacifist position and the pacific ideal. Second, the failure to attend to the ideal/nonideal distinction in rejecting pacifism makes a caricature out of certain traditionally pacifist positions (such as non-violent resistance) and also undermines the role that the pacific ideal plays in non-pacifist approaches to war like just war theory.

The potential incompatibility between the pacific ideal and some versions of pacifism goes back to the divergence over the biblical sources, especially the pacifist generalization of the hard sayings and the challenge to that generalization based on a distinction between retaliatory violence and rebuke or punitive violence. If a pacifist remains convinced, in light of the pacific ideal, that punitive (not merely retaliatory) violence is never permitted-i.e., that Jesus' command against non-retaliation is applicable to all forms of violence, and that it is absolute, not merely prima-facie — he must remain so on nonideal grounds. His grounds for remaining so could be that he sincerely believes the good to be gained from punitive violence would never outweigh the cost, or that obedience to the apparent command of Jesus is the best approach in the face of calculations that seem impossible to make with confidence, or that on the spectrum from rebuke to potentially lethal violence we encounter a boundary that we ought not cross, or finally (and controversially) that Christians ought not to get their hands dirty in such business even if others have to. (What does this say about 
God's dirty hands? Perhaps that somehow God can do this work without dirtying His hands). What cannot be the pacifist's grounds is the idea that a just peace is possible without confronting evil, or that pure non-resistance to evil, strictly speaking, is even an option for Christians, or that the biblical record presents an obvious open-and-shut case on the matter. Niebuhr castigated pacifists for what he considered to be a watering down of Jesus' command from pure non-resistance to non-violent resistance, but Niebuhr's conception of the relation between love and evil is fundamentally flawed. He failed to recognize that the silent and innocent submission to evil that is exemplified by Jesus' trial and execution is itself a reproach to evil, a communication of what is good and true in the face of what is wicked and false. It is a reproof, and no just peace is possible without reproof, because a just peace for humanity is a peace among repentant and forgiven sinners. Pace Niebuhr, pure nonresistance to evil is not agape love, it is heresy. The irony here is that pacifism is so often rejected for being too idealistic, as if the ideal itself was pure non-resistance, when the only pacifism that means anything, or that counts as truly Christian, is decidedly a nonideal pacifism. The pacific ideal does not rule out nonideal pacifism as a Christian ethic of war, but it does circumscribe the grounds upon which nonideal pacifism could be justified or articulated if it is to remain coherently and consistently Christian.

The fact that there are nonideal grounds for traditionally pacifist approaches (such as non-violent resistance) to conflict brings us to the second problem with conflating pacifism and the pacific ideal, which is that by failing to attend to the ideal/nonideal distinction, a caricature is made of both the pacific ideal and nonideal pacifism. The non-violent resister acknowledges that Christians live in a nonideal world that is unlikely to be changed, or easily changed, through human efforts. Nevertheless he holds that the best interpretation of the 
love command in nonideal circumstances requires refraining from violence. Working that command out in reality means taking a non-violent position even in the face of horrific and unjust violence, not because consequences do not matter to the non-violent resister, but because he is willing to accept horrific consequences out of his conviction that the hard sayings require it, and because the witness of such non-violent resistance is the tool that God will use to overcome evil. What a nonideal pacifist is not committed to do-and will not do if he believes in the pacific ideal-is to ignore the necessity of resisting evil or the terrible moral costs of not doing so. Assessing the viability of this pacifist strategy is beyond the scope of this paper. But the reasoning of non-violent resistance is not ruled out, it seems to me, by the pacific ideal. In fact, it ironically looks similar to the reasoning that is employed by the just war tradition: a just peace is intended, certain absolute prohibitions on conduct are enjoined, and moral costs are weighed and accepted. Moreover, what the just warrior and the nonideal pacifist clearly have in common is that neither loses sight of the reality of war or the traces of moral imperative that remain in its context. The moral claims (i.e., the love command) that bind them are not suspended simply because they inhabit a non-ideal world.

The pacific ideal is caricatured when it is rejected as merely an ideal. The just war tradition's rejection of pacifism is not a rejection of the pacific ideal, because it incorporates that ideal, and the moral injunctions it embodies, into its own reasoning. It is true that Biggar and others criticize pacifism for wishful thinking and for the horrific consequences that it seemingly accepts too blithely. ${ }^{31}$ However, Biggar rejects those consequences not merely because they are horrific_even a justified war is horrific-but because they are

\footnotetext{
31 Biggar does not blithely reject the strategy of non-violent resistance, nor should he in light of the periodic efficacy of non-violent movements; see In Defence of War , 19-21, 30-31; nevertheless he does reject it as universally binding, as do I.
} 
morally unacceptable. The Christian just warrior rejects pacifism not because it insists upon the binding nature of the love command, but for its faulty generalization and application of that command, not because it insists upon the continuing relevance of the pacific ideal, but because of the false continuity it draws between the ideal and the nonideal. For the pacifist, Christian behavior under partial compliance looks much the same as it does under full compliance. For the just warrior, it may and should be modified to include a forceful yet loving resistance to evil. The question is not whether the love command is relevantstructurally both positions preserve a commitment to its relevance in the move from ideal to nonideal circumstances_-but how it should be interpreted to rightly guide nonideal Christian action. So the basic opposition between the traditions of just war and non-violent resistance (what I have taken to be the most prevalent form of nonideal pacifism) is fundamentally a quarrel over nonideal theory, whereas the rejection of the two varieties of realism described above was a matter of both ideal and nonideal theory. The same would go for any variant of pacifism, also described above, that failed to have a truly just peace as its ideal.

So far I have argued for the relevance of the pacific ideal in evaluating a variety of realist and pacifist approaches to conflict. What about the just war tradition? Can anything constructive be said about that tradition in light of the pacific ideal as I have articulated it? The best way to say something constructive about the just war tradition is to apply one's reasoning to the criteria of jus ad bellum and jus in bello that are traditionally associated with it. There is no single authoritative list of these criteria or their order of priority, but following Biggar, whose list is fairly exhaustive and whose logic is straightforward, they are as follows: ${ }^{32}$ For jus ad bellum: just cause, legitimate authority, right intention (including public declaration), last

\footnotetext{
32 See Biggar, In Defence of War, 251-253, on the proper ordering and content of the just war criteria.
} 
resort, proportionality, and prospect of success. For jus in bello: discrimination (intentional attacks on noncombatants prohibited) and proportionality at the warfighting level (and I add right intention here as well, as the warfighting level). Biggar's logic is that just cause is logically prior to all else, because only if it is being fought to resist, reverse, or punish a grave injustice can war be justified. Legitimate authority is next, because even if the cause is just, who may do the fighting? $?^{33}$ Right intention is logically secondary to just cause but equally necessary: is the just cause the fundamental reason for going to war, exclusive of all other concerns, and not used as a pretext for another agenda? A just cause, rightly intended and recognized as such by the public, and pursued by a legitimate authority, is not, however, enough to justify a war. A justified war must be necessary (is war the last resort?), proportional (are the inevitable evils of the war 'outweighed' by the cause and are the means sustainable and not subversive of a just peace?) and feasible (is there a genuine prospect of success for vindicating the just cause and achieving a just peace?). The jus in bello criteria are part of ensuring that a justified war is proportional and non-subversive of just peace, so they are entailed by the jus ad bellum criteria, and yet they are binding even if jus ad bellum is not satisfied, due to the continuing relevance of the norms of peace as described in Part III.

With the criteria before us, we can now evaluate them in light of the pacific ideal. I propose to do this, not by going through each criterion in order, but in order of the key relationships of ideal to nonideal theory, and looking at the just war criteria as they relate to those relationships: a 'realistic' ideal as the aimed-for ideal, moral permissibility in terms of absolute prohibitions, moral permissibility in terms of weighing moral costs, and finally, political possibility and likely effectiveness in transition towards the aimed-for ideal.

${ }^{33}$ I note that for Childress legitimate authority is logically prior to just cause; someone first has to decide the cause is just (435). 
Just cause is prior to all else in the pacific ideal as well, because whatever just cause is being fought for-the most basic being resisting a state's unjust aggression against another or punishing grave injustices against its own people-must necessarily be a constituent of a just peace. Because the pacific ideal is an ideal of reproved and repentant sinners, the just cause includes not only the protection and vindication of the innocent but also reprobative punishment of the unjust aggressor. ${ }^{34}$ Thus the just cause relates directly to the aimed-for ideal, without which no violence could be justifiably set into motion. Furthermore, it must be a 'realistic' ideal, specified clearly enough to help condition the other criteria that will flow from it, such as last resort, proportionality, and prospect of success. Without a clearly-envisioned just outcome, against which judgments of necessity, proportionality, and feasibility can be made, just cause fails to provide the needed guidance. For this reason, just cause is also likely to be the most public of the just war criteria, and it should be publicized, not only for the sake of the soldiers and citizenry who will bear the cost of war, but also for the sake of the enemy, who should be given the chance to repent or retort.

With regard to moral permissibility in terms of absolute prohibitions, the criteria that most obviously provide such guidance are discrimination and right intention. Discrimination means that noncombatants cannot be intentionally targeted. Justified violence, like rebuke, must be aimed at those who are judged to be doing wrong, not indiscriminately at innocent bystanders, which would be a further violation of just peace, not an act in support of it. If it is true that there is a prima-facie prohibition on harming others which can only be overridden by a sufficiently important just cause, then there is an absolute prohibition on any harm that

\footnotetext{
34 Another jus ad bellum criteria which sometimes makes the list but I do not discuss at length here, is worth mentioning: relative justice, which is meant to ensure that the 'just' side in a justified war does not mistake itself as perfectly just, or worse, as holy warriors fighting a depraved enemy; this is important to keep in mind when speaking of reprobative punishment.
} 
is not so justified, and that prohibition continues to apply to those who are noncombatants. In war, however, there are foreseeable harms to noncombatants-e.g., if pursuing an enemy takes one into a populated area- that are not intended, but that under the just war tradition's understanding of discrimination, may be justified. However, they can only be justified under further conditions: that extra risk is taken to prevent them and that proportionality and last resort are observed, so that the moral costs of violation are adequately taken into account. ${ }^{35}$

There is a sense, then, that the only truly absolute obligation in nonideal policy according to the just war tradition is right intention. And this applies even to battlefield action against the enemy. Biggar, citing diaries, memoirs, and military policies, goes to great lengths to argue that a right and loving intention can be maintained, not only at the level of war planning and treatment of non-combatants, but even on the battlefield against enemy soldiers. ${ }^{36}$ He does so by articulating the doctrine of double effect, which distinguishes effects that are intended—chosen and wanted—from those that are regretfully accepted—chosen but not wanted (95). But it is not enough that unintended effects are unwanted; the soldier is still responsible for them; if he is to remain inculpable, those effects must be justified:

To be responsible for causing evil is to be required to give a justifying account for causing it — to show that it was not caused needlessly, in the sense that it could have been avoided; or in vain, in the sense that it undermined the good effect for whose sake it is being tolerated; or disproportionately, in the sense that it did not 'outweigh' the good achieved....Good intentions are not enough. (96)

Biggar thus relates the criteria of last resort ("not caused needlessly...could have been avoided"), discrimination ("undermined the good effect for whose sake it is being tolerated"), and proportionality ("did not 'outweigh' the good achieved") to right intention as a way of saying

\footnotetext{
35 The requirement that extra risk be taken to avoid such harms is Michael Walzer's addition to the doctrine of double effect, see Walzer, Just and Unjust Wars, 151-159.

36 See Biggar, In Defence of War, Chapters 2 and 3.
} 
that intention alone is not enough to justify an evil. But he goes on to say elsewhere that the purpose of proportionality is at least in part to ensure that violence is rightly intended:

Whether ad bellum or in bello, jus requires proportionality. But why is it important, and what does it mean in practice? The purpose of the criterion is to have the use of violence governed by the rightly intended moral ends, partly to limit the damage caused, and partly to provide a way of measuring the sincerity of intention. $(113-14)^{37}$

Thus, right intention is at the heart of moral permissibility in nonideal just war theory.

Clearly, moral permissibility in terms of absolute prohibitions quickly spills over into moral permissibility in terms of weighing moral costs. The moral costs in question result from the transition in a justified war from an unjust to a just peace. Some of those costs are, to use Simmons' term, matters of 'transitional unfairness', such as foreseen or unforeseen effects on noncombatants who are touched, perhaps even ravaged, by the war. The criterion of discrimination, as described above, requires that extra risk be taken to minimize such costs. It could also be thought to apply when rectification has to be made that affects those who innocently relied upon unjust arrangements (e.g., the citizens of an aggressive state). Ideally, these costs would be imposed upon those responsible for wrongdoing, but that is unlikely to be possible, in which case they must be weighed as moral costs. The other obvious moral costs that need to be taken into account are borne by those who take upon themselves the responsibility of waging the justified war, and these are manifold and also impossible to foresee with accuracy: the time, treasure, and emotional toll upon a country's citizenry, the risk of life and limb by soldiers and their loved ones and communities, and finally, not to be underestimated, the moral and psychological costs involved in perpetrating regrettable, even if justified, violence. In all of these cases, the central just war criteria that apply are last resort

\footnotetext{
37 Biggar's discussion of proportionality is quite extensive and grounded historically in two wars whose justice is widely questioned, World War I and the 2003 invasion of Iraq; it is, next to his emphasis on intentionality, likely to be the most controversial aspect of his account of just war theory. Unfortunately, space prohibits an adequate discussion of it here.
} 
and proportionality, with prospect of success closely related. Obviously last resort applies: if a moral cost is unnecessary, it should not be incurred. As for about 'weighing' those that should, what kind of calculation should be made? At one point, Biggar says that an evil can be said to be disproportionate if it is either unnecessary or subversive of the just cause (113-14). The problem with equating disproportionate with unnecessary is that the criterion of necessity is already captured in last resort, at least at the level of jus ad bellum. As for being nonsubversive, this is partly addressed by the criterion of discrimination, in that an action taken that is intentionally or directly at odds with the just cause is forbidden. How is one to measure how much evil can be borne before an act becomes subversive by way of being disproportionate? There be no better way than to say that a proportionate cause must be a sustainable cause, both for those who take up the responsibility of waging the justified war and for those on whose behalf it is fought (148). And this need for an honest judgment of sustainability presses in the direction of publicizing the costs of a justified war, just as just cause itself is pressed in the direction of being publicized by the need for a realistic aimed-for ideal. The consequences of war are impossible to foresee, but an honest, public attempt should be made to see them, even the unintended ones or at least the likelihood of them.

Finally, with regard to the regulative nonideal criteria of political possibility and likely effectiveness, understood as fulfilling the strong 'transitional' role that Simmons envisions for nonideal policy, the just war criteria that most obviously fill this role are proportionality understood as sustainability, discrimination understood as non-subversive activity, and prospect of success. Any nonideal action that is politically unsustainable, that has no chance of success, or that undermines the aimed-for ideal, making it impossible or less likely to be achieved, should not be undertaken. This is not as straightforward as it may sound. Success in pursuit 
of a just peace may mean no more than a consistent moral witness to such a peace even in the face of certain death and destruction. In this case, non-violent witness or a hopeless war in pursuit of a just cause may have much in common. But such a war would be sustainable in that those who fought it would be willing to suffer defeat, and it might not undermine a just peace as much as continued complicity and submission to an unjust peace. These are the difficult calculations that may have to be faced in the nonideal pursuit of justice.

My hope is that this reconstruction of the just war criteria in light of the relationship between ideal and nonideal theory, and particularly in light of the pacific ideal, will illuminate the interrelationships between the criteria and the roles that they play in nonideal decision making. This especially seems to be the case for the many uses to which proportionality is put, the close relationship between right intention and the criteria that are sometimes referred to as 'prudential' (i.e., proportionality, last resort, and in its non-subversive aspect, discrimination), and the pressure on both the just cause and the moral costs to be clarified and publicized for the various 'prudential' criteria (including prospect of success) to do their work. Moreover, a firm and 'realistic' conception of the pacific ideal, with the commitments to love and justice that it embodies, gives the idea of just cause and everything that flows from it a needed compass and content, which applies not only to the just war criteria, but also to the nonideal traditions of pacifism and realism that were discussed above. The pacific ideal seems relevant, then, to Christian theoretical reasoning about love, justice, peace, conflict, and war.

What is its practical relevance to Christians, to those who do not reason theoretically about war? The pacific ideal, like the just war tradition chastens immorality in warfare if taken seriously. It denies a license to kill for those who would seek one, forbidding soldiers to kill indiscriminately, self-indulgently, or self-righteously. However absurd or tragic the 
circumstances of war may be, they do not absolve the soldier of moral responsibility. ${ }^{38}$ It denies rulers a license to amoral power, the pursuit of 'national interest' or ulterior political and economic agendas not aimed at a just peace. National interests are rightly factored into the criterion of proportionality as costs to be weighed, but they do not stand alone as justifying agendas. It denies citizens a license to indulge fantasies of 'national greatness' that involve their country in unjustified wars. It names 'greatness' a false idol if it is not just.

Whether the pacific ideal actually chastens immorality in warfare, however, depends a great deal upon the relationship among citizens, rulers, and soldiers in the political society in question. In a pluralist context, where many rulers, advisors, and soldiers are unlikely to have explicit commitments to the love command, what meaningful effect could it have? The intentions of rulers and soldiers are impossible to control even if they may often be revealed, but they are influenced by the intentions of citizens in their political societies, as is revealed by the kinds of appealing speech that successful politicians use to gain their support. And in the same way that just causes need to be publicized in order for the just war criteria to work effectively, so do the intentions of citizens committed to the pacific ideal, not only by voting patterns, but also by the speech they use to talk publicly about justice, peace, and war.

The one criteria that I did not discuss above in the context of ideal and nonideal theory was that of legitimate authority, which traditionally has meant that a society's ruler, in consultation with his advisors, decides on the justice of war. In the context of pagan Rome, it may have sufficed to pray for the emperor to act justly, but in the modern context, where there exists at least the self-understanding that the citizen has a role in governance and the

\footnotetext{
${ }^{38}$ For those who may doubt the absurdity or tragic character of war as it is actually experienced by soldiers on the ground, see Paul Fussell, "My War: How I Got Irony in the Infantry”, Harper's Magazine, January 1982, 40-48, who depicts the 'good war', World War II, as "cruel” and "swinish".
} 
reality that rulers are sensitive to public opinion on these matters, non-articulation of one's pacific commitment is problematic. The legitimacy of a ruler's decision regarding war is not determined solely by the consent of the citizenry. But confidence in the rulers of a liberal democracy to consistently make just decisions is related to the health of the political culture, and that reality further presses the need for public witness to the pacific ideal.

Moreover, a corrupt political culture has the potential to corrupt rulers and soldiers who might otherwise be inclined towards a just peace. There are at least two features of modern political culture that suggest corruption of this sort: First is the disconnect between political speech giving reasons for war and the actual intentions of rulers deciding on war. Concern is often rightly focused on the latter, but assuming for the moment that the cause is just and rightly intended, if the reasons given to citizens are not the right reasons, this is evidence of corruption in the political culture, and it risks corrupting rulers who might otherwise have just intentions. From the perspective of the just war tradition, it is highly problematic for the criteria of legitimate authority and right intention. Second is the disconnect between the public honoring of soldiers and the justice of the wars in which they are asked to fight. To the extent that honor is given unconditionally even if a war is unjust, the soldiers are at risk of being corrupted. From a just war perspective, this is problematic for the connection between jus ad bellum and jus ad bello; while the latter apply regardless of the former, speech about courage and sacrifice cannot ennoble a war that is fundamentally unjust. In both of these cases, the solution is internalization and a change in speech, not by the rulers or the soldiers, but by the citizens and the politicians who talk about war, and the pacific ideal can guide such speech. For Christians, it provides not only an opportunity to 
live out the love command in their political lives, but to bear witness to its legitimacy publicly, and thereby to bear witness to the integrity of their faith.

Upon being told that they must exercise these virtues in order to rightly participate in political life, many Christians who survey the political landscape will undoubtedly say, "Of course people ought to be motivated by the right reasons and ought to be honest about their reasons when they push policies and seek votes, but don't you see, that's not the way the political world works." Note the similarity with the standard objection to pacifism as described above. This objection simply assumes, rather than intelligently contending, that the existence of nonideal circumstances eviscerates the relevance of the normative ideal, when in reality, the relationship between the two circumstances is far more continuous and complex. They fail to see that the political landscape itself is shaped not only by those who do not comply with the pacific ideal, but also by those who do, or try to, just as the landscape of war is shaped by both immoralists and those who fight pacifically.

The pacific ideal does present an ideal to be aspired to in the sense that Chesterton uses the term in the epigraph. It is an ideal theory, to be sure, but ideal in the right way, and because of that eminently relevant to the realities of life. But it is only effective where it is understood and internalized. If the pacific ideal can be allowed to challenge our speech as well as our intentions, my contention is that it would be the kind of ideal, difficult but not impossible, that is needed for shaping Christian military and political life, and the kind of ideal that vindicates the robustness and timeless validity of the Gospel's love command. 


\section{Sources Cited}

Allen, David, Getting Things Done, New York: Penguin Books 2015.

Augustine of Hippo, The Political Writings of St. Augustine, Chicago: Regnery Gateway 1962.

Biggar, Nigel, In Defence of War, Oxford: Oxford University Press 2013.

Brewer, Talbot, The Retrieval of Ethics, Oxford: Oxford University Press, 2009.

Childress, James, "Just-War Theories: The Bases, Interrelations, Priorities, and Functions of their Criteria" Theological Studies, Vol. 39, No. 3, September 1978.

Fussell, Paul, “My War: How I Got Irony in the Infantry”, Harper's Magazine, January 1982.

Niebuhr, Reinhold, The Nature and Destiny of Man, "Why the Christian Church is Not Pacifist", Christianity and Power Politics, 1940.

"Is the Bombing Necessary?", Christianity and Crisis, Vol. 4, No. 5, April 3, 1944.

Ramsey, Paul, The Essential Paul Ramsey: A Collection, New Haven: Yale University Press 1994.

Rawls, John, A Theory of Justice, Cambridge: Belknap Press of Harvard University Press 1999. The Law of Peoples, Cambridge: Harvard University Press, 1999.

Simmons, A. John, "Ideal and Nonideal Theory", Philosophy \& Public Affairs Vol. 38, No. 1, Wiley Periodicals 2010.

Walzer, Michael, Just and Unjust Wars, $4^{\text {th }}$ ed., New York: Basic Books, 2006.

Wolterstorff, Nicholas, Justice in Love, Grand Rapids: Eerdmans 2011. 